\title{
Potential of Hot-Dry-Rock Geothermal Energy in the Eastern United States
}

\section{A Report to the United States Congress under Section 2502 of Public Law 102-486 (The Energy Policy Act of 1992)}

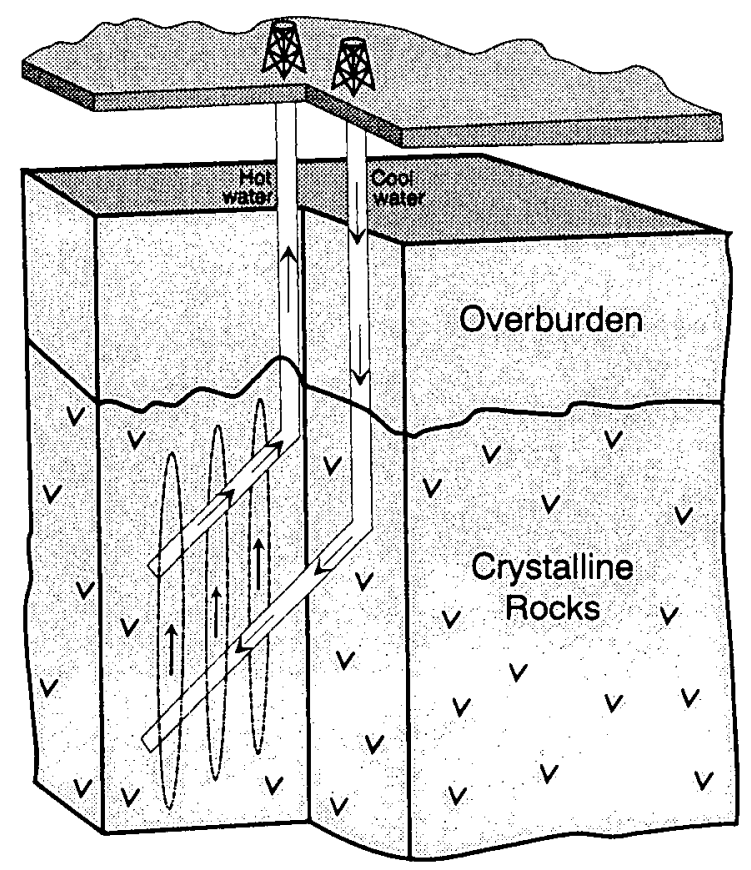

\section{U.S. Geological Survey}

in collaboration with the U.S. Department of Energy

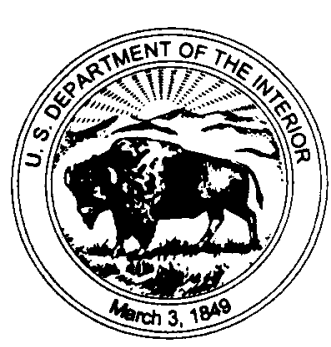

USGS Open-file Report 93-377 November 1993

This report is preliminary and has not been reviewed for conformity with U.S. Geological Survey editorial standards or the North American Stratigraphic Code. Any use of trade, product, or firm names is for descriptive purposes only and does not constitute endorsement by the U.S. Government. 


\section{DISCLAIMER}

This report was prepared as an account of work sponsored by an agency of the United States Government. Neither the United States Government nor any agency Thereof, nor any of their employees, makes any warranty, express or implied, or assumes any legal liability or responsibility for the accuracy, completeness, or usefulness of any information, apparatus, product, or process disclosed, or represents that its use would not infringe privately owned rights. Reference herein to any specific commercial product, process, or service by trade name, trademark, manufacturer, or otherwise does not necessarily constitute or imply its endorsement, recommendation, or favoring by the United States Government or any agency thereof. The views and opinions of authors expressed herein do not necessarily state or reflect those of the United States Government or any agency thereof. 


\section{DISCLAIMER}

Portions of this document may be illegible in electronic image products. Images are produced from the best available original document. 


\title{
Potential of Hot-Dry-Rock Geothermal Energy in the Eastern United States
}

\author{
A Report to the United States Congress under \\ Section 2502 of Public Law 102-486 \\ (The Energy Policy Act of 1992)
}

\author{
U.S. Geological Survey \\ in collaboration with the U.S. Department of Energy \\ USGS Open-file Report 93-377 \\ November 1993
}

This report is preliminary and has not been reviewed for conformity with U.S. Geological Survey editorial standards or the North American Stratigraphic Code. Any use of trade, product, or firm names is for descriptive purposes only and does not constitute endorsement by the U.S. Government.

Cover illustration is adapted from Figure 4.1 of Erdwärme, a brochure on geothermal energy, by F. Rummel, O. Kappelmeyer and O. A. Herde, Geo-meß-systeme GmbH., Bochum, 1991. 


\section{TABLE OF CONTENTS}

TABLE OF CONTENTS $\ldots \ldots \ldots \ldots \ldots \ldots \ldots \ldots \ldots \ldots \ldots \ldots \ldots \ldots \ldots$ i

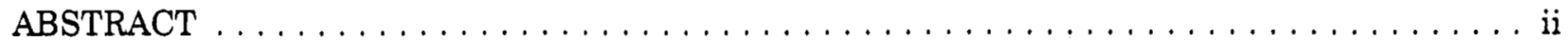

EXECUTIVE SUMMARY $\ldots \ldots \ldots \ldots \ldots \ldots \ldots \ldots \ldots \ldots \ldots \ldots \ldots \ldots \ldots \ldots \ldots \ldots$

LIST OF ACRONYMS $\ldots \ldots \ldots \ldots \ldots \ldots \ldots \ldots \ldots \ldots \ldots \ldots \ldots \ldots \ldots$

I. INTRODUCTION AND BACKGROUND $\ldots \ldots \ldots \ldots \ldots \ldots \ldots \ldots \ldots \ldots \ldots$

II. DEVELOPMENT AND STATUS OF HDR TECHNOLOGY $\ldots \ldots \ldots \ldots \ldots \ldots \ldots \ldots \ldots$

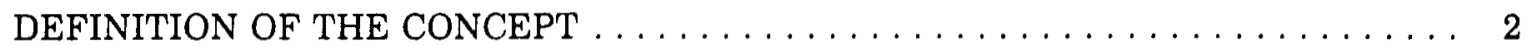

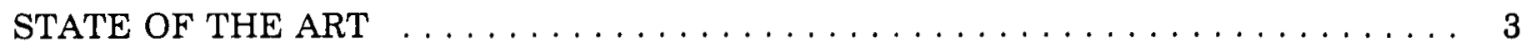

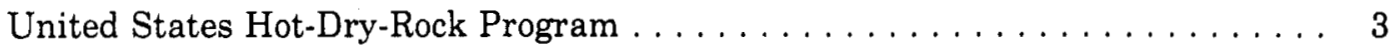

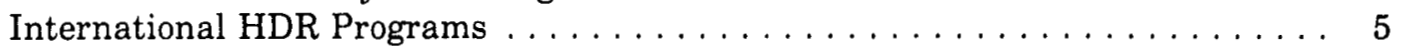

III. USGS/DOE WORKSHOP - POTENTIAL OF HDR RESOURCES IN THE EASTERN

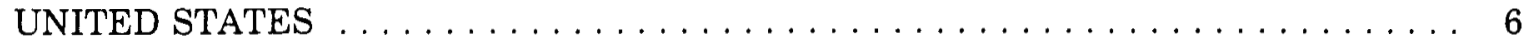

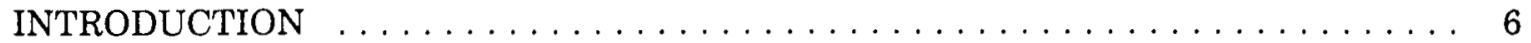

WHAT IS HOT-DRY-ROCK (HDR) $\ldots \ldots \ldots \ldots \ldots \ldots \ldots \ldots \ldots \ldots \ldots \ldots$

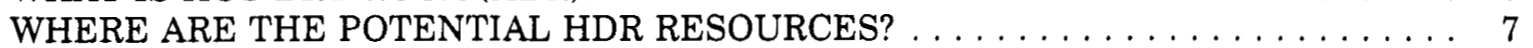

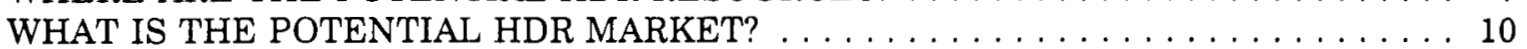

WHAT ARE THE TECHNOLOGICAL BARRIERS TO HDR? . . . . . . . . . . . . . 12

IV. CONCLUSIONS AND RECOMMENDATIONS $\ldots \ldots \ldots \ldots \ldots \ldots \ldots \ldots \ldots \ldots \ldots$

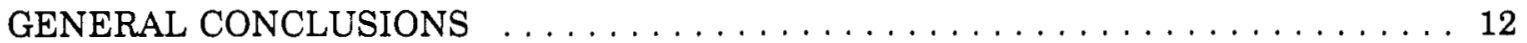

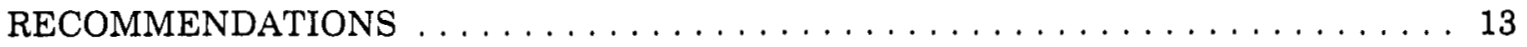

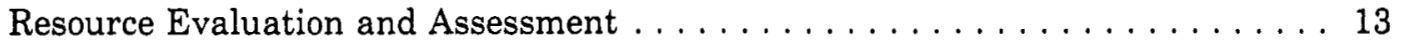

Technology Development . . . . . . . . . . . . . . . . . . . . 14

Implementation Strategy $\ldots \ldots \ldots \ldots \ldots \ldots \ldots \ldots \ldots \ldots \ldots \ldots$

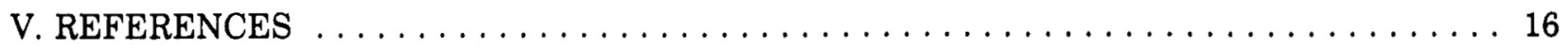

APPENDIX A: WORKSHOP PROGRAMS $\ldots \ldots \ldots \ldots \ldots \ldots \ldots \ldots \ldots \ldots$

APPENDIX B: LIST OF ATTENDEES $\ldots \ldots \ldots \ldots \ldots \ldots \ldots \ldots \ldots \ldots \ldots \ldots \ldots \ldots$

APPENDIX C: SUMMARY OF EPRI WORKSHOP $\ldots \ldots \ldots \ldots \ldots \ldots \ldots \ldots \ldots \ldots$

APPENDIX D: DETAILED SUMMARIES OF USGS/DOE PANEL DISCUSSIONS $\ldots \ldots \ldots 25$

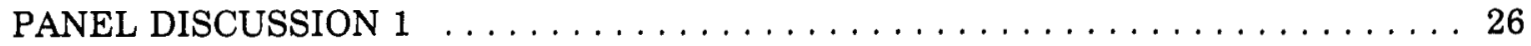

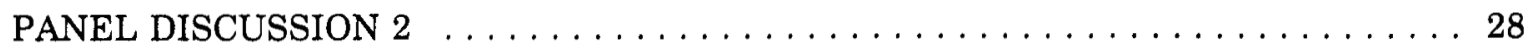

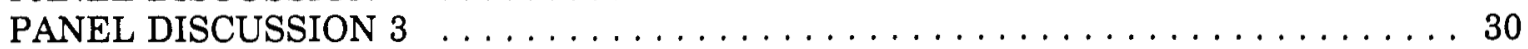

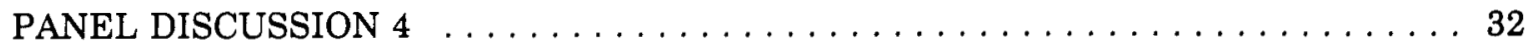

APPENDIX E: REPORTS OF THE LOS ALAMOS TEAM $\ldots \ldots \ldots \ldots \ldots \ldots \ldots \ldots \ldots$

APPENDIX F: ASSESSMENTS OF GEOTHERMAL RESOURCES OF THE U.S. . . . . . . 36

APPENDIX G: AUTHORS AND CONTRIBUTORS $\ldots \ldots \ldots \ldots \ldots \ldots \ldots \ldots \ldots \ldots \ldots$ 


\begin{abstract}
The extraction of thermal energy from beneath the earth's surface has been defined as "heat mining". This process can take the form of simply tapping hot fluids at depth or it can involve injection of fluids into permeable rock or even the creation of fracture permeability by injection of fluids into hot impermeable rock. The latter process has been termed "hot-dry-rock" (HDR). It is estimated that there is sufficient energy available for this class of heat mining to supply a significant fraction of the world's energy needs without the environmental problems associated with the combustion of hydrocarbons or nuclear fission.

More than 20 years and several hundred million dollars have been devoted so far to the study of HDR. The feasibility of the technology has been demonstrated at several locations worldwide, and the parameters of an economically viable HDR electrical generating facility have been defined. The demonstration facilities have been too small for commercial development however, and some key parameters of these sites (e.g., flow impedance) are outside the range considered necessary for successful commercial exploitation of the technology. These difficulties notwithstanding, it seems prudent to continue research and development activities in HDR, particularly in view of the large potential resource base and the probable future constraints on hydrocarbon use.

Section 2502 of the National Energy Policy Act of 1992 directed the U.S. Geological Survey to hold a workshop to discuss the potential for hot-dry-rock (HDR) heat mining in the eastern United States. For the purposes of that workshop, held in Philadelphia, PA on January 15, 1993, the eastern United States was defined as those states from the Great Plains to the eastern seaboard. Within this region, heat mining is presently restricted to residential heating and cooling (as demand-side management), spas and a few demonstration projects for institutional space/process heat. Under present economic and technological constraints, mining heat for electrical power generation is not feasible in the eastern United States. Given a modest boost in electrical rates, power generation from hydrothermal sources might prove economic in two or three regions of unusually high surface heat flow. Unresolved technical barriers to the development of HDR heat mining in the East turn primarily on the issues of drilling costs and the general applicability of hydrofracturing technology to compressional stress fields typical of upper crustal rocks in the East. The public's acceptance of geothermal heat pumps suggests that if these technical barriers can be overcome, HDR may, indeed, provide a significant fraction of the energy needed in the next century.
\end{abstract}




\section{EXECUTIVE SUMMARY}

\section{Objectives of the Report}

In Section 2502 of Public Law 102-486, the Energy Policy Act of 1992, The Congress of the United States directed that the U.S. Geological Survey, "in collaboration with the Secretary of Energy", hold a workshop on the potential for hot-dry-rock (HDR) geothermal resources in the eastern United States. Congress also instructed that a report of the workshop be prepared that would specifically:

1. Review the status of recoverability of HDR energy in the eastern United States.

2. Determine what geologic, technological, and economic obstacles need to be overcome to make the utilization of HDR energy feasible.

\section{Scope of the Report:}

No guidance was given in the legislation as to what exactly constitutes the "eastern United States". Rather than adopting a narrow definition such as the strip of Atlantic coastal states, the workshop steering committee opted to consider the eastern half of the contiguous United States, an area bounded by the western margin of the Great Plains and the Atlantic Ocean.

The report first establishes a working definition for hot-dry-rock. It then goes on to identify the most promising areas for further exploration based on the expectations of high temperatures at depths that are economically drillable with present or somewhat enhanced drilling technology. An analysis of market conditions follows. Finally, the technological barriers (including those imposed by geological parameters) are considered.

\section{Context of the Report:}

In reviewing the findings of the workshop, it should be borne in mind that it took place during one day. This time constraint meant that some important issues, most notably hydrology, were given no explicit consideration. The workshop attendees represented a broad spectrum of expertise and opinion. They included skeptics of HDR technology as well as fervent advocates. The report attempts to provide a balanced view of the proceedings. The conclusions and recommendations represent a majority view, if not a strict consensus of those attending.

\section{Findings of the Report:}

1) Definition. The term "hot-dry-rock" originally had a very restricted, specific meaning; viz. completely impermeable homogeneous crystalline rock at a temperature that can provide useful amounts of energy. It might be desirable to broaden the definition to include much of what has come to be termed "heat-mining" i.e., "simply the extraction of heat or thermal energy from underground". No rock is truly dry and very little is hot $\left(>250^{\circ} \mathrm{C}\right)$ at depths that can be drilled cost-effectively. The creation of artificial reservoirs and the stimulation of existing ones by injection of fluids can both be viewed as HDR within a continuous spectrum of heat-mining 
techniques.

2) Location of Potential HDR Resources. As a first approximation, the sites with the highest temperatures at shallowest depths are the best prospective HDR locations. The most effective strategy for identification of areas of high temperature entails the combination of reliable temperature data from deep holes with temperatures estimated from shallow heat-flow holes and data on thermal conductivity. Other factors including the local stress field, hydrologic regime, the market and the environment will come into play in choosing the most desirable HDR development sites.

No thermal anomalies in the East are attributable to young-to-contemporary volcanic or other igneous activity; most are in areas of relatively high natural radiogenic heat production in crystalline basement rocks blanketed by sediments of low thermal conductivity, or above areas of upflow of water heated deeper in the crust. Temperatures of potential heat-mining sites would rarely exceed $150^{\circ} \mathrm{C}\left(300^{\circ} \mathrm{F}\right)$ at depths of $4 \mathrm{~km}(13,000 \mathrm{ft})$ in the East. Based upon the existing incomplete data set, the most promising areas of interest (top of crystalline basement at depths of less than $4 \mathrm{~km}$ or 13,000 ft) are in western New York, in Pennsylvania, along the Delmarva Peninsula of Delaware, Maryland and Virginia, northern Nebraska and southern South Dakota, along the Wisconsin-Illinois border and in northwestern Louisiana. The areas of interest expand considerably if the target temperatures are lower, say 60 to $80^{\circ} \mathrm{C}\left(140\right.$ to $\left.180{ }^{\circ} \mathrm{F}\right)$.

Systematic studies of heat flow, hydrology, geology and stress are required on both regional and local scales to provide a data-base sufficient for the evaluation and assessment of potential HDR resources in the eastern United States. This data-base should be obtained, to the extent possible, using "holes of opportunity" drilled by industry and government for other purposes. It will probably be necessary, however, to drill research coreholes in areas where no other data are available and to identify the most promising prospects.

3) Potential HDR Market. Relatively modest increases in energy costs or increased demand for non-hydrocarbon forms of energy could create a significant market for direct-use applications of HDR, particularly for residential and institutional heating and cooling. The New York State Energy Research and Development Authority has a demonstration geothermal heating plant at a site near Auburn, NY. While not strictly HDR, this facility does involve injection into the reservoir to stimulate production. New York is presently seeking a suitable site for a direct-use HDR demonstration. A related technology, geothermal heat pumps, has made significant inroads in some parts of the eastern United States. Public acceptance has been strong, and some utilities have found that heat pumps provide a strong tool for "demand-side management" of generating capacity. For institutional uses and for cluster-housing developments, direct-use HDR could provide another option for environmentally benign energy sources.

In constant dollars (adjusted for inflation), real electricity prices in the 20th century declined by about a factor of 3 between 1940 and 1950, with very stable prices (adjusted for inflation) since then, in comparison to some extreme swings in the prices of petroleum and its derivatives. The cost of drilling and completing an HDR well currently increases exponentially with depth and is 2 to 6 times higher than that for an oil or gas well of the same depth. When applying an economic analysis specifically to the eastern United States, well depths required for a given temperature are much greater than for the western United States, with a consequent increase in the cost. Bringing the price of electricity generated from HDR into the competitive realm for temperature gradients typical of the East will be heavily dependent on dramatic improvements in drilling technology to lower well costs. 
4) Technical Barriers to HDR. There are certain design criteria for an HDR facility (i.e., the values of parameters such as flow rate, injection pressure, reservoir impedance, reservoir volume, etc.) that must be attained for economic production of energy from hot-dry-rock reservoirs. These criteria can be reasonably constrained by data from the United States and international hot-dryrock experiments. A central and as yet unanswered question is whether hot-dry-rock reservoirs can be engineered to meet the economic design criteria or whether the earth's natural properties limit the range of working conditions to less than the design goals. In other words, can reservoir impedance be low enough and reservoir volume large enough to allow the high fluid-flow rates and long reservoir life necessary for commercial production of hot-dry-rock energy?

Although environmental effects from HDR development are expected to be easily addressed, induced seismicity could be a serious impediment in some locations. Field evidence in the United States, United Kingdom and Japan indicate low seismic risk; however, rock-breakdown pressures in the eastern United States may be high, because the regional stress regime is predominately compressive. One earthquake associated with HDR development that is felt by the populace could create serious negative public reactions.

Drilling costs are one of the largest obstacles to the cost effectiveness of HDR technology. The challenge is to create a drilling technology with costs that increase linearly, rather than exponentially, with depth.

\section{Report Recommendations:}

\section{A. Resource Evaluation and Assessment}

1) Fill in the gaps in heat-flow coverage of the eastern United States to provide a better quantitative basis for resource assessment.

2) Assemble a data-base including heat-flow data, reliable deep temperature data from industry sources, and thermal conductivity data.

3) Analyze the existing data on regional stress in terms of its implications for hydraulic fracturing and induced seismicity.

4) Perform in situ stress measurements by hydrofracture in conjunction with boreholes drilled for heat flow and other purposes.

5) Review and update existing resource assessments to include more information on candidate HDR sites.

6) Inventory water supplies and perform detailed hydrologic studies near candidate HDR sites.

\section{B. Technology Development}

1) Complete a long-term flow test at Fenton Hill, New Mexico.

2) Drill a second production well at Fenton Hill, New Mexico to permit enhanced production flow rates and higher energy extraction rates. 
3) Coordinate present efforts to stimulate increased production in existing hydrothermal fields with HDR research.

4) Select an HDR prototype site in the eastern United States.

5) Re-establish formal cooperation among United States, European and Japanese heat-mining research projects.

6) Increase Government-industry joint research efforts on advanced drilling technologies with the goal of decreasing the cost of drilling deep wells.

\section{LIST OF ACRONYMS}

CRADA Cooperative Research and Development Agreement

DOE United States Department of Energy

EPACT

Energy Policy Act of 1992 (P.L. 102-486)

EPRI

Electric Power Research Institute

HDR

Hot-Dry-Rock

LANL

Los Alamos National Laboratory

MIT

Massachusetts Institute of Technology

USGS

United States Geological Survey 


\section{INTRODUCTION AND BACKGROUND}

The Energy Policy Act of 1992 (EPACT) was passed in October of 1992 as Public Law 102486. EPACT specifically requires the United States Geological Survey (USGS) to carry out research into the feasibility and availability of hot-dry-rock geothermal energy (hereinafter referred to as HDR). Section 2502 directs the USGS to convene a workshop dealing with HDR in the eastern United States. Specifically:

SEC.2502. HOT-DRY-ROCK
GEOTHERMAL ENERGY IN
EASTERN UNITED STATES
The United States Geological
Survey, in collaboration with
the Secretary of Energy, shall
convene a workshop of
interested governmental and
private parties to discuss the
regional potential for hot-dry-
rock geothermal energy in the
eastern United States and to
determine what geologic,
technological, and economic
obstacles need to be overcome
to make the utilization of hot-
dry-rock energy feasible. The
workshop shall be convened
within 6 months after
enactment of this Act and the
United States Geological
Survey shall submit a report to
Congress within 6 months after
the workshop containing a
summary of the findings and
conclusions of the workshop.

Coincidentally, the Electric Power Research Institute (EPRI) was planning to hold a oneday workshop on "Potential of HDR Resources for the U.S. Electric Utility Industry", to be hosted by Philadelphia Electric Company on January 14, 1993. When the EPACT requirements became known, representatives of the USGS contacted the EPRI workshop organizer to explore the possibility of adding a day to accommodate the congressionallymandated USGS workshop on the eastern
United States. EPRI agreed to the proposal and the USGS workshop was scheduled for January 15, 1993, also at Philadelphia Electric Company's headquarters. An ad hoc steering committee was then formed to coordinate the two workshops.

Appendix A contains the programs for the two workshops. Names of speakers and panel chairs are shown in boldface type. Appendix B lists the names and affiliations of those who attended either or both of the workshops. A brief summary of the EPRI workshop, which preceded the USGS workshop, is presented in Appendix C. The proceedings of the EPRI workshop will be published by that organization as a workshop report primarily for distribution to its member utilities. The substance of the keynote addresses for the USGS/DOE workshop has been published in various forms by those speakers (Blackwell and Tester) and those publications are listed in the bibliography of this report. No formal proceedings of the panel discussions are planned, but summaries are given in Appendix D.

Holding the workshops on successive days provided a unique opportunity for communication between two groups that rarely mingle, namely the geothermal research community and representatives of public utilities and independent power producers. The steering committee found it quite easy to persuade people recruited for one of the workshops to attend both, with the result that there was a satisfactory degree of overlap between the two (see Appendix B).

In Section II, the history of national and international development of HDR technology is reviewed, together with aspirations of the various research groups regarding future directions. Section III gives a summary of the USGS workshop. Section IV summarizes the findings and conclusions as required by $\mathrm{PL}$ 102-486. In that section, the USGS is guided primarily by the deliberations and recommendations of the various panels, but also by the requirements of Section 2501 of EPACT, which directs the USGS to initiate appropriate government-industry cooperative 
projects in HDR and to "identify, select, and classify those areas throughout the United States that have a high potential for hot-dryrock geothermal energy potential".

\section{DEVELOPMENT AND STATUS OF HDR TECHNOLOGY}

\section{DEFINITION OF THE CONCEPT}

The hot-dry-rock (HDR) concept grew from ideas conceived in 1970 by a group of scientists and engineers at Los Alamos National Laboratory (LANL). They reasoned that a fraction of the vast store of thermal energy in the crust of the Earth could be extracted by using hydraulic fracturing techniques already employed by the petroleum industry. The group worked for almost two years developing a practical method for extracting thermal energy from the numerous regions of the Earth's crust with emphasis on hot -- but essentially dry -- rock at moderate depths. The group's preliminary studies suggested that rock temperatures in excess of $160^{\circ} \mathrm{C}$ at depths less than $6 \mathrm{~km}$ appeared to be suitable for HDR development.

As the HDR concept was originally conceived, this method of extracting geothermal energy would emulate the dominant heat-transfer mechanism occurring in natural hydrothermal systems, where heat is transported from deeper regions of permeable-hot rock to near-surface reservoirs by the convective flow of ground water. In the group's patented, engineered geothermal system, a large, permeable volume of hot rock created by hydraulic fracturing would be interconnected to a heat exchanger at the surface by a pair of drilled holes, forming a closed, convective circulation loop, as illustrated in Figure 1.

In the past two decades, there have been variations (e.g., multiple production wells) to the original HDR concept, but the basic method of recovering thermal energy from naturally heated, impermeable rock at accessible depth remains valid. Some proponents of HDR suggest that the current definition is too narrow. A more general definition might be in line with that of Garnish and others (1992) viz:

"... any geothermal system where reinjection is necessary to extract heat at a commercial rate for a prolonged period."

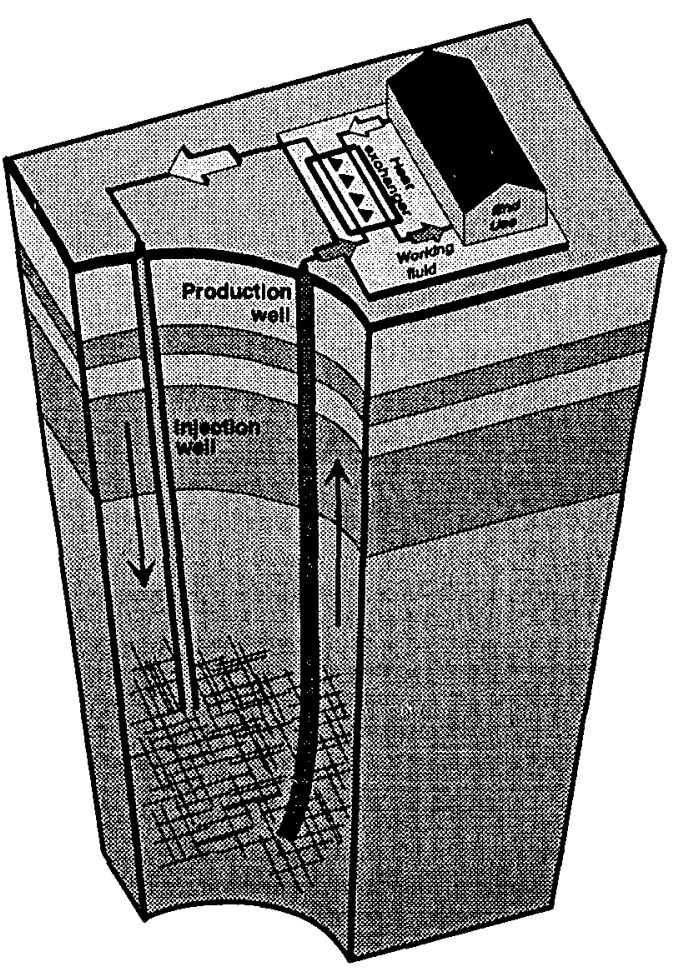

Figure 1. Schematic diagram of a Fenton Hill-type HDR system (source: LANL HDR Group). Water is pumped down an injection well, is heated as it percolates through artificially opened fissures in the rock, and returns through the production well to the power plant or other facility on the surface.

Placing the HDR concept into the broader context of "heat-mining" as defined by Armstead and Tester (1987), would facilitate understanding and acceptance by those not familiar with it. Even though a broader definition may become preferred in the future, the current field programs focus on the engineering of systems in impermeable, crystalline basement rocks. 


\section{STATE OF THE ART}

Through 1992, there were United States hotdry-rock projects and two major field programs in the world aimed at developing hot-dry-rock (HDR) technology: Fenton Hill (United States), Hijiori (Japan), and Soultz (a joint FrenchGerman effort). The status of these programs, as well as other areas, is addressed below.

\section{United States Hot-Dry-Rock Program}

The first hot-dry-rock geothermal energy system in the world was completed at Fenton Hill, New Mexico in 1977. It was enlarged in 1979 by additional hydraulic fracturing, and operated successfully for more than a year, including a 9-month continuous test. The system was constructed by drilling a well to a depth of approximately $3,000 \mathrm{~m}$ into granitic rock at about $185^{\circ} \mathrm{C}$; hydraulic fractures were produced at about 2,600 $\mathrm{m}$ depth; and after redrilling the production well to intersect those fractures, hydraulic communication was achieved. Pressurized water was circulated through the fractures, bringing heat to the surface in the range of $135{ }^{\circ} \mathrm{C}$ to $140{ }^{\circ} \mathrm{C}$ at thermal energy outputs of up to $5 \mathrm{MW}$, some of which was used to operate a $60 \mathrm{~kW}$ binarycycle, electrical generator. System operation was essentially trouble-free, and there were no detectable scaling, plugging, corrosion, or environmental effects.

To extend technology to the temperatures and rates of heat production required to support a commercial power plant, construction of a larger, deeper system was initiated at Fenton Hill in 1979. During this second stage of technology development, two new wells, about $50 \mathrm{~m}$ apart at the surface, were drilled directionally, the deeper one to a vertical depth of $4,390 \mathrm{~m}$, where the maximum rock temperature was $327{ }^{\circ} \mathrm{C}$. To provide the horizontal separation required to thermally isolate a series of planar, vertical fractures, the bottom $1,000 \mathrm{~m}$ of each hole was drilled $35^{\circ}$ from the vertical, while the shallower hole was drilled $380 \mathrm{~m}$ vertically above the deeper one. Unfortunately, the attempts at hydraulic fracturing did not produce the predicted results. The fracture systems produced were planar, but they did not connect the two wells hydraulically. It was therefore necessary to redrill the bottom of the original production well to intersect several of the fractures produced by the largest hydraulic fracturing experiment, and to establish good flow connections to the original injection well (Figure 2). These fractures and the two wells constituted the underground heat-extraction loop. Later, the original injection well was redrilled, because of mechanical problems and completed as a production well, to create the present system.

A series of stimulations and flow tests established the initial reservoir flow impedance, outlet temperature, and fluid chemistry. An 84-hour flow test through the fractures below $3,650 \mathrm{~m}$ was completed in July 1985 , in a section of the fractured reservoir where the rock temperature was about $265^{\circ} \mathrm{C}$.

During 1986, several preliminary experiments and an Initial Closed-Loop Flow Test of the system were conducted over a period of 30 days. Results of the test were encouraging. Temperature of the produced fluid increased throughout the 30-day test, to a maximum of $192{ }^{\circ} \mathrm{C}$, and thermal-energy production increased correspondingly, to nearly $10 \mathrm{MW}$. Overall flow impedance (defined as pressure drop across the reservoir $\div$ production flow) through the fractured reservoir decreased throughout the test. The recovery of injected water increased under conditions of constant pressure and was continuing to improve at the close of the test.

The earlier HDR field-test results prompted planning and preparations for a long-term flow test of the HDR reservoir at Fenton Hill. The production wellbore was reworked to assure that it could withstand extended circulation tests. A full-scale, surface-test facility was designed and constructed. Major subsystems were checked out and preliminary system tests carried out between October 1991 and March 1992 , followed by a long-term flow test starting 

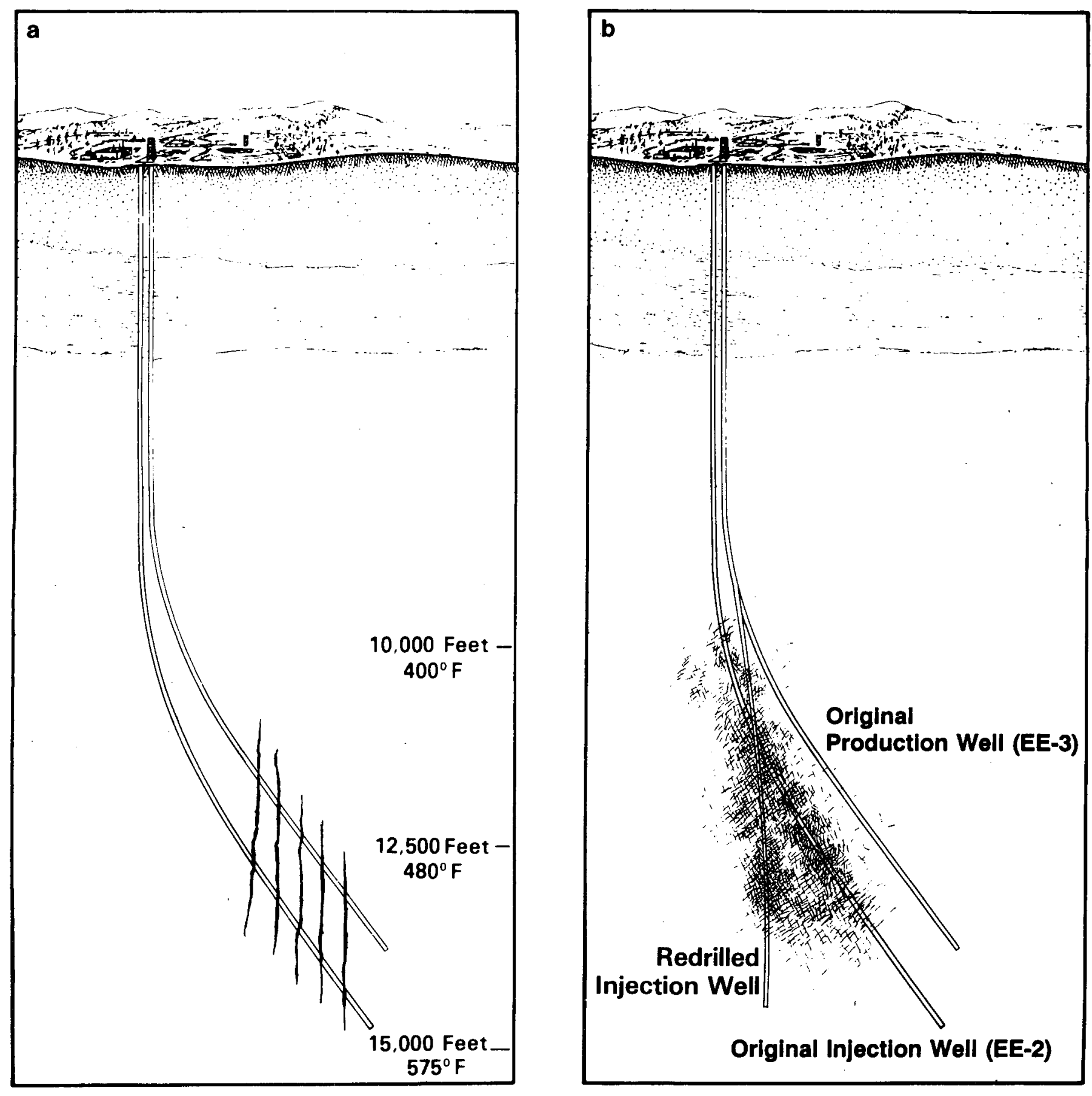

Figure 2. a) Original well-design for the Fenton Hill reservoir showing predicted configuration of hydraulically induced fractures. b) Trajectory of redrilled injection well into reservoir created by slippage along pre-existing fractures. 
in April 1992. This test ended after 4 months of continuous operation when the injection pumps failed unexpectedly.

During the 4-month test, water was circulated through the Fenton Hill HDR reservoir to produce thermal energy on a 24-hour-a-day basis, under almost constant operating conditions. Over this period of 113 days, energy production was maintained at an average level of about 4 thermal megawatts, with only a few, short interruptions due to electric power outages. The system operated 2,716 hours for an on-line availability factor of $99 \%$. There was no evidence of thermal drawdown of the reservoir. Tracer test results indicated that flow paths were lengthening which, in turn, implied that increased access to the reservoir rock was occurring as the test proceeded. Water consumption averaged about $11 \%$ during the test, but about $17 \%$ of this use could be directly attributed to increased storage in newly opened or enlarged rock joints within the reservoir.

In addition to the Fenton Hill project, HDR projects at other locations are under consideration. The City of Clearlake, California, with financing from the California Energy Commission (CEC), is evaluating the potential of $\mathrm{HDR}$ energy development within its boundaries. Resource assessments (Burns and others, 1992) have been conducted, and the project has now progressed to the drilling stage. In addition, the State of Arizona, with cost-sharing from DOE, is in the process of jointly funding an exploratory well to assess the thermal properties of a potential HDR site in the Springerville-Alpine, Arizona area.

\section{International HDR Programs}

Several countries are now involved in HDR development, and it could become an important source of clean energy, but fundamental problems remain. A large reservoir of thermal energy exists at accessible depths in the earth's crust (Armstead and Tester, 1987); however, commercial feasibility has yet to be demonstrated. It is not clear that the Earth's physical properties will allow construction of such facilities. A thorough investigation of the geologic and hydrologic framework and also the technology of extracting heat from the earth is necessary to resolve remaining issues. Nevertheless, the prospect of mining significant amounts of thermal energy using HDR technology and the pioneering efforts of the United States HDR program fostered similar experiments in the following countries:

JAPAN. The Japanese have a vigorous, wellfunded research and development effort in HDR technology. The current budget is in the range of \$5-6 M a year, more than twice that of the present United States effort. Interest in HDR began as early as 1978 under various arrangements. From 1981 to 1986, under the auspices of the International Energy Agency (IEA), the Japanese participated in a joint HDR study program at Fenton Hill, involving the United States and Germany. Currently, they are working at several sites in Japan and developing advanced concepts, such as using multiple production wells. During the summer of 1991, the Japanese drilled a third production well at their HDR facility near Hijiori, north of Tokyo. While water-loss problems had plagued the Japanese HDR program in the past, about $80 \%$ of the injected water was recovered during a 3-month flow test of this system in the autumn of 1991 (Yamaguchi and others, 1992). Given their development plans, the Japanese are about 2 years away from an extended flow test similar to that at Fenton Hill. At two of the Japanese sites, HDR systems have been developed in rock hot enough to produce useful amounts of electricity.

GREAT BRITAIN. The United Kingdom is situated in an area of low thermal gradient $\left(<30^{\circ} \mathrm{C} / \mathrm{km}\right)$, where HDR resources are deep and difficult to reach. Studies at the Camborne School of Mines (CSM) since 1977, included design for a prototype, deep $(6 \mathrm{~km})$, hydrofractured, HDR reservoir at Rosemanowes, where the rock temperature is sufficient for electricity generation, yet low enough to avoid many of the early physical problems (e.g., cable and logging tool failures) associated with high temperatures at the Fenton Hill HDR project (Parker, 1990). 
The Rosemanowes project consisted of several phases. The first phase was conducted at the shallow depth of $300 \mathrm{~m}$ and was designed primarily as a cost-effective means of understanding the natural fracture system. The system was then extended to nearly 3,000 $\mathrm{m}$ in the temperature range of $100{ }^{\circ} \mathrm{C}$. Numerous fracturing, circulation, and gelpropping experiments followed.

Despite optimism in the early 1980's and expenditure of $\$ 72 \mathrm{M}$, HDR technology in the United Kingdom has not progressed to the point of commercial feasibility. Consequently, in early 1991, the British decided to cease underground work at Rosemanowes and to participate in HDR work sponsored by the European Community.

THE EUROPEAN COMMUNITY. Germany and France, in union with the European Community, are sponsoring a significant HDR effort at Soultz in northeastern France (Bresee, 1991; Baria and others, 1992). The site is an oil field that was abandoned in the late 1950's. The heavily faulted granitic basement of the upper Rhine Valley is overlain by some 1,000 to $1,400 \mathrm{~m}$ of sedimentary rocks. The top of the granite is as hot as $120^{\circ} \mathrm{C}$ in some areas. At the Soultz HDR project, two deep wells $(2,000$ and $2,200 \mathrm{~m})$ reached the granitic basement at about $1,400 \mathrm{~m}$ depth. Temperature at the base of the sedimentary cover is $124{ }^{\circ} \mathrm{C}$ and the bottom-hole temperature in the granite is about $150{ }^{\circ} \mathrm{C}$. From these results, the basement appeared suitable in principle as an HDR resource, and deepening of one well to $3,500 \mathrm{~m}$ is planned.

A consortium of European industrial firms is planning a $\$ 300 \mathrm{M}, 10$-year program aimed specifically at development of HDR in areas of low thermal gradient. A scientific prototype of a commercial HDR system is planned. The project is scheduled to begin in 1994 under the sponsorship of the European Community. Currently, locations in France, Germany, and the United Kingdom are being evaluated as experimental sites. The final site-selection process is expected to be completed within the next two years.
RUSSIA. Recently, a new HDR development program was begun at a tungsten mine in the former Soviet Union. At a site near Tirniauz in the Caucasus Mountains of Russia, scientists have been working to create an HDR system based on the Fenton Hill model to provide direct thermal energy for year-round operation of the mine. Tungsten is a valuable commodity and could provide collateral for the financing necessary to carry this project forward at a time of national economic chaos. The first hydrofracture experiment at Tirniauz was carried out in 1991. Currently, the project is suspended due to political uncertainties.

Garnish and others, (1992) reported that with respect to some key parameters, notably production rate and reservoir impedance, current technology lags far behind in meeting requirements for a "commercial" HDR system. In particular, the predictability of patterns of hydrofracture is a key technical issue. A related problem is that of reducing impedance, or resistance to flow, of substantial amounts of fluid through the system.

\section{USGS/DOE WORKSHOP - POTENTIAL OF HDR RESOURCES IN THE EASTERN UNITED STATES}

\section{INTRODUCTION}

Section 2502 of EPACT provided the following guidance as to the purpose of the workshop and the product to be delivered as part of this report:

1) Review the status of recoverability of HDR energy in the eastern United States.

2) Determine what geologic, technological, and economic obstacles need to be overcome to make the utilization of HDR energy feasible. 
The format of the EPRI workshop (Appendix C) was very successful in imparting the latest information on HDR from a variety of perspectives and in providing a forum for exchange of ideas regarding technology development and marketing. To achieve the EPACT objectives with maximum participation by interested and knowledgeable people, a less formal and more flexible format was adopted for the congressionally-mandated workshop. The program is presented as the second page of Appendix A. Both morning and afternoon sessions were opened by a keynote speaker who was followed by two topical panels addressing the issues raised in Section 2502.

Rather than provide a chronological narrative of the workshop deliberation, this section has been organized to provide the most logical development of the response to the Congressional instructions. An issue decided before the workshop was convened, but on which there is broad consensus in terms of both geology and geothermal potential, is what constitutes the "eastern United States". Rather than adopting a narrow definition, such as the strip of Atlantic coastal states, the steering committee opted to consider the eastern half of the contiguous United States, an area bounded by the western margin of the Great Plains and the Atlantic Ocean (Figure 3).

\section{WHAT IS HOT-DRY-ROCK (HDR)?}

The term "hot-dry-rock" was coined by engineers and originally had a very restricted, specific meaning; viz. completely impermeable crystalline rock at a temperature that can provide useful amounts of energy. The rationale for assembling this panel was, in part, to examine the directions that HDR has taken since originally defined and to assess the desirability of broadening the definition to include much of what has come to be termed "heat-mining" defined by Armstead and Tester (1987) as "simply the extraction of heat or thermal energy from underground". Despite the fact that the target parameters for commercial HDR are well known, very little progress has been made toward the goal of commercialization during the past decade. The greatest technical challenge in that regard appears to be achieving significantly lower flow impedance within the artificially created reservoir. The ambient stress and nature of existing fracture systems may limit the extent to which low impedance can be engineered. An area of research that has been largely neglected is that of naturally occurring fractures. These often open preferentially, as opposed to the creation of new fractures, and may well result in fracture configurations that yield optimum impedances. Much research remains to be done on the relationship among ambient stress field, breakdown pressure, fracture growth and ultimately, reservoir productivity.

A working definition of HDR remains elusive. No rock is truly dry and very little is hot at depths that can be drilled cost-effectively with current technology. Reservoir-stimulation procedures commonly used in the most transmissive reservoirs (e.g., Heber and East Mesa in the Imperial Valley of California) do not involve deliberate hydraulic fracturing, and are thus not within even a broad definition of HDR. The creation of artificial reservoirs and the stimulation of existing ones might best be viewed as part of a continuous spectrum of heat-mining techniques. In any event, research and development activities aimed at reservoir stimulation by injection should be coordinated with what is now viewed as purely HDR activities. The Japanese program is providing a model for this type of coordination.

\section{WHERE ARE THE POTENTIAL HDR RESOURCES?}

It is possible to identify regions of promise in the eastern United States, bearing in mind that the western United States has a significantly higher potential for HDR. The "average" heat flow for the eastern United States is $55-60 \mathrm{~mW} \mathrm{~m}^{-2}$. This average is, however, not useful for assessing HDR or other geothermal resources, because the heat flow varies from place to place, depending on geologic and hydrologic conditions. To a first 
approximation, the most promising areas for electrical generation are the areas of highest heat flow in Figure 3 (Blackwell and others, 1991; Blackwell and Steele, 1992). This simplistic view must be modified to some extent by considering such factors as location with respect to potential markets, depth to crystalline basement, the thermal conductivity of sedimentary cover, and the environmental impact of HDR development. The most effective strategy for identification of areas of high temperature entails the combination of reliable temperature data from deep holes with temperatures estimated from shallow heat-flow holes and data on thermal conductivity (Figure 4). If shallow radioactively-derived heat is neglected, temperature at depth can be estimated from:

$$
\mathrm{T}(\mathrm{z})=\mathrm{T}_{0}+\mathrm{qz} / \mathrm{k}
$$

where $T(z)$ and $T_{0}$ are temperature at depth $z$ and surface temperature, respectively, $q$ is heat flow and $\mathrm{k}$ is the average (harmonic mean) thermal conductivity between the surface and depth $z$. Once the distribution of subsurface temperature is known, other factors, including the local stress field, hydrologic regime, the market and the environment become relevant. Thus, identification of areas with potential HDR resources is based on heat-flow data, depth to appropriate crystalline reservoir rocks and the physical and chemical properties of those reservoir rocks. Data sets include regional geophysical surveys to evaluate the depth, shape and extent of candidate reservoir rocks and thermal, hydrologic and other borehole data that are crucial to understanding the heat sources.

No eastern thermal anomalies are attributable to young-to-contemporary volcanic or other igneous activity; most are in areas of relatively high radioactive heat production blanketed by sediments of low thermal conductivity, or above areas of upflow of water heated deeper in the crust. Temperatures of potential heat-mining sites will rarely exceed $150{ }^{\circ} \mathrm{C}$ at depths of 4 $\mathrm{km}$ in the East. Based upon the existing incomplete data set, the most promising areas of interest (top of crystalline basement at depths of less than $4 \mathrm{~km}$ ) are in western New York, in Pennsylvania, along the Delmarva Peninsula of Delaware, Maryland and Virginia, northern Nebraska and southern South Dakota, along the Wisconsin-Illinois border and

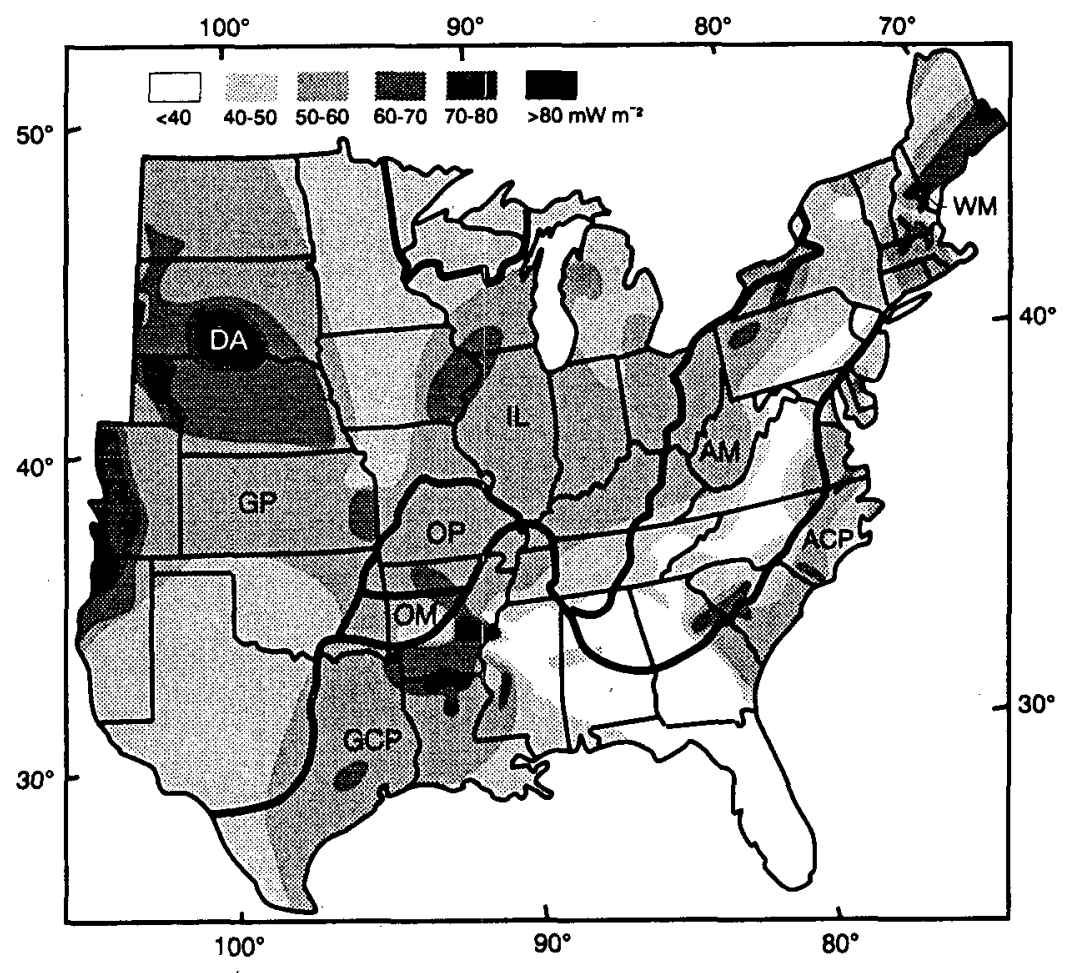

Figure 3. Heat flow of the eastern United States (adapted from Blackwell and others, 1991). Abbreviations: GP, Great Plains; DA, Dakota Aquifer; IL, Interior Lowlands; OP, Ozark Plateau; OM, Ouachita Mountains; GCP, Gulf Coastal Plain; AM, Appalachian Mountains; $A C P$, Atlantic Coastal Plain; WM, White Mountains. 


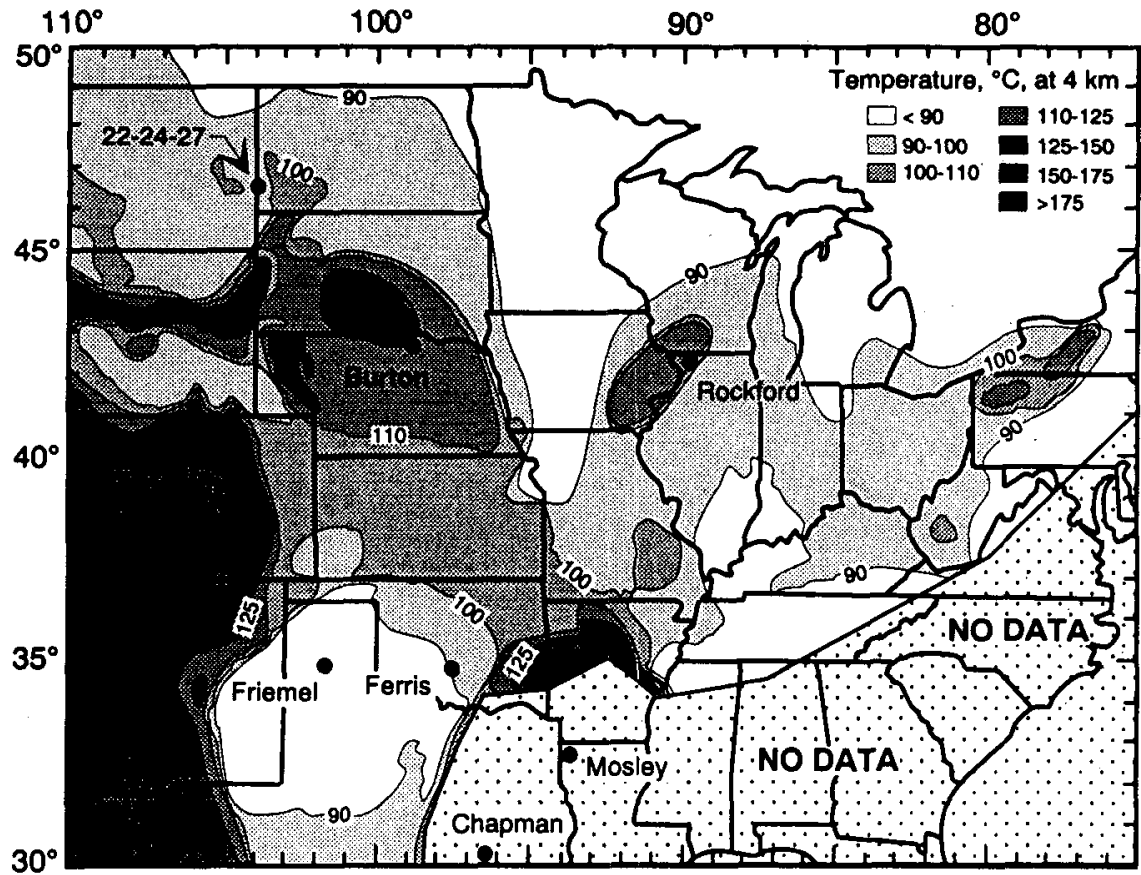

Figure 4. Temperatures at a depth of $4000 \mathrm{~m}$ in the eastern United States as inferred from heat flow and thermal-conductivity data. The regions labelled " no data" have no information on depth to basement and thus, no thermal conductivity profiles. in northwestern Louisiana (Figure 3). At some eastern localities, a combination of hydrologic factors and low-conductivity sedimentary cover can result in temperatures that are comparable to western high heat-flow zones. The northwestern Louisiana site (Figure 5) is a good example. Here, a temperature of $135^{\circ} \mathrm{C}$ was measured at a depth of about $3 \mathrm{~km}$. The areas of interest expand considerably if the target temperatures are lower $\left(60\right.$ to $\left.80^{\circ} \mathrm{C}\right)$.

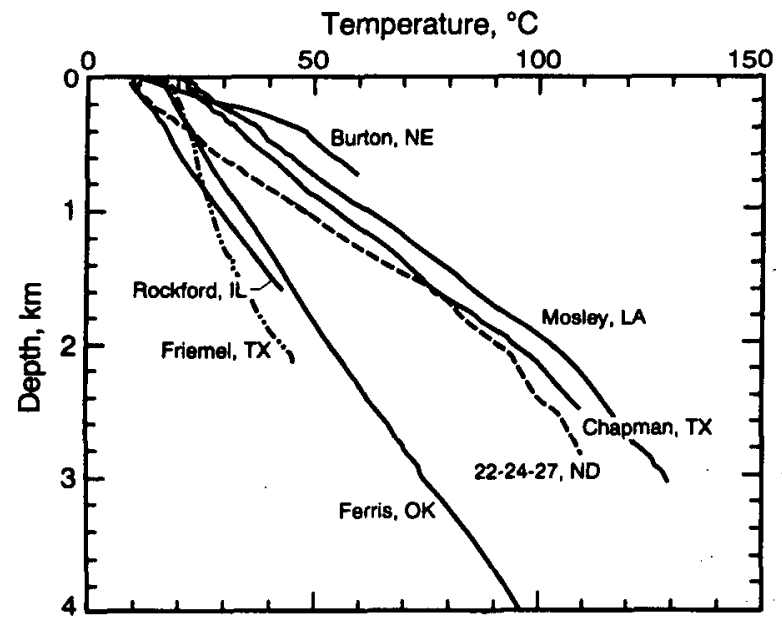

Figure 5. Temperature profiles at localities shown in figure 4.
Although heat flows in the White Mountains of New England (WM, Figure 3) are anomalously high (up to $80 \mathrm{~mW} \mathrm{~m}^{-2}$ ) by eastern United States standards, temperatures at drillable depths are not, because there is no insulating sedimentary cover. With present technology and foreseeable market conditions, geothermal energy applications there are probably limited to direct use.

Gravitationally driven convection in some areas of the Great Plains produces anomalously high heat flow which results in temperatures of about $100^{\circ} \mathrm{C}$ at depths of 2 to $3 \mathrm{~km}$. One such region occurs along the border between Nebraska and South Dakota, within the Dakota Sandstone aquifer (DA, Figure 3).

Systematic studies of heat flow, hydrology, geology and stress are required on both regional and local scales to provide a data base sufficient for the evaluation and assessment of potential HDR resources in the eastern United States. This data base should be obtained, to the extent possible, using "holes of opportunity" drilled by industry and government for other purposes. It will probably be necessary, however, to drill dedicated core holes in areas 
where data are unavailable and to outline the most promising prospects.

\section{WHAT IS THE POTENTIAL HDR MARKET?}

Much of the research on the market for HDR geothermal energy has taken place at the Energy Laboratory of the Massachusetts Institute of Technology (MIT) (Tester and Herzog, 1990; 1991; Tester, 1992).

Based on data provided by Adelman and Lynch of the MIT Center for Energy and Environmental Policy Research, electrical energy prices in the 20th century declined by about a factor of 3 between 1940 and 1950, with very stable prices (adjusted for inflation) since then, in comparison to some extreme swings in the prices of petroleum and its derivatives (Figure 6). The cost of drilling and

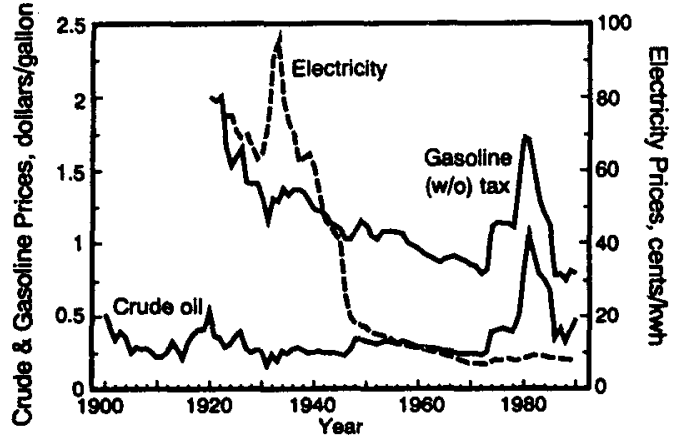

Figure 6. Historical energy prices, 1900-1990, adjusted for inflation in constant 1990 dollars (source: Adelman and Lynch, MIT Center for Energy and Environmental Policy Research, 1992).

completing an HDR well currently increases exponentially with depth (Figure 7) and is 2 to 6 times higher than that for an oil or gas well of the same depth. When applying the economic analysis specifically to the eastern United States, well depths required for a given temperature are much greater than for the western United States, with a consequent increase in the cost, particularly for electrical generation (Table 1). Drilling costs are one of the largest obstacles to the cost effectiveness of

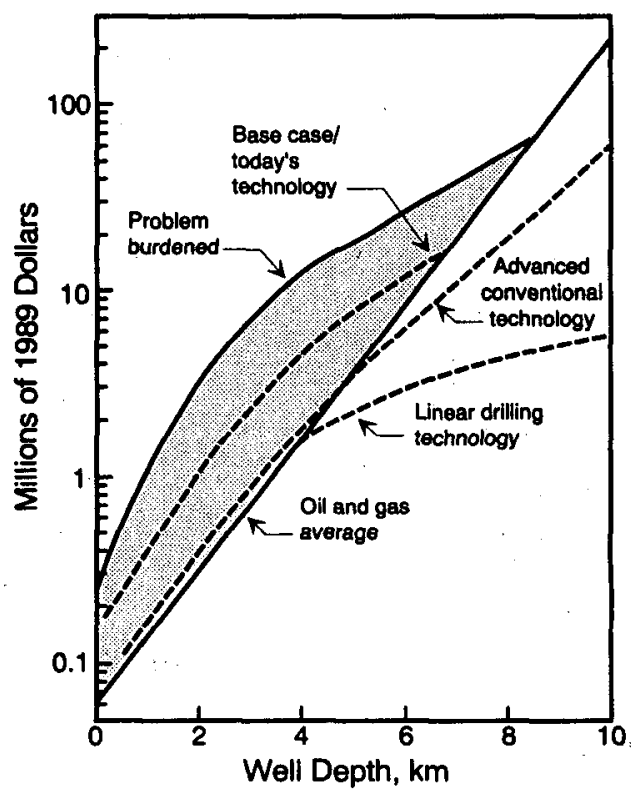

Figure 7. Projected HDR well costs in 1989 dollars for various assumptions regarding technology.

Table 1. Range of parameters and attributes for eastern versus western hot-dry-rock resources.

\begin{tabular}{|c|c|c|}
\hline Characterlstlc & East & West \\
\hline Gradients & $20-40^{\circ} \mathrm{C} / \mathrm{km}$ & $30 \cdot 80^{\circ} \mathrm{C} / \mathrm{km}$ \\
\hline Well depths & $9 .-7 \mathrm{~km}$ & $7.5 \cdot 3.5 \mathrm{~km}$ \\
\hline Water availability & $\begin{array}{c}\text { Good to } \\
\text { excellent }\end{array}$ & $\begin{array}{c}\text { poor to } \\
\text { fair }\end{array}$ \\
\hline $\begin{array}{c}\text { Cogeneration } \\
\text { potential }\end{array}$ & $\begin{array}{c}\text { excellent } \\
\text { to good }\end{array}$ & $\begin{array}{c}\text { fair to } \\
\text { good }\end{array}$ \\
\hline $\begin{array}{c}\text { Direct heating } \\
\text { potential }\end{array}$ & $\begin{array}{c}\text { excellent } \\
\text { to good }\end{array}$ & $\begin{array}{c}\text { fair to } \\
\text { good }\end{array}$ \\
\hline $\begin{array}{c}\text { Plant sizing } \\
\text { flexibility }\end{array}$ & good & fair \\
\hline
\end{tabular}

HDR technology (Figures 7 and 8). The challenge is to create a drilling technology with costs that increase linearly, rather than exponentially, with depth. One candidate technology for reducing costs could be thermal spallation where a fuel oil-compressed air (or oxygen) mixture is used to produce a hot, supersonic flame that causes the rock to spall. In one test using a flame jet, penetration rates in the Conway granite of New Hampshire. reached as high as 30 meters per hour, roughly 
5 to 10 times faster than conventional rotary drilling in soft, sedimentary rock. There are other improvements in drilling technology under consideration and testing, but drilling costs for HDR technology deployment in the eastern United States will probably remain a major obstacle for quite some time.

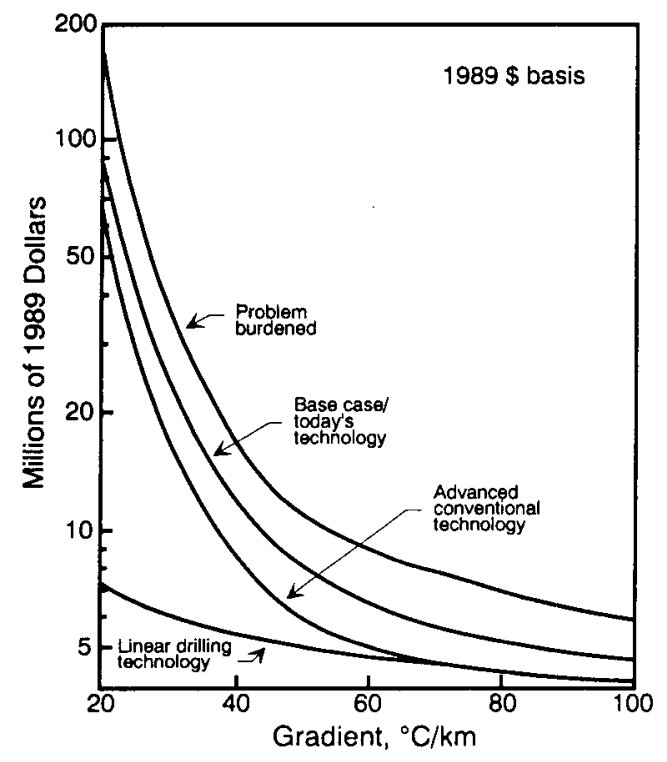

Figure 8. Predicted HDR busbar electricity prices as a function of resource grade, expressed by average geothermal gradient $\left({ }^{\circ} \mathrm{C} / \mathrm{km}\right)$ for four different technology scenarios (adapted from Tester, 1992).

For an average gradient of $30^{\circ} \mathrm{C} / \mathrm{km}$ in the East, the MIT model predicts electricity costs of 25 to 30 cents $/ \mathrm{kWh}$, or about 5 to 8 times more than todays costs of base-load power from fossil fuels. However, the model indicates heat for direct uses could be produced from HDR at 1.5 to 2 times current costs. Other technologies, such as nuclear energy, fusion, solar energy, and biomass present significant problems and drawbacks not shared by HDR. HDR offers the nation a large, ubiquitous, noncarbon energy source, making it a very attractive candidate for further technology development.

The economics of thermal energy recoverability in the eastern United States for non-electrical uses is of particular importance. Geothermal heat pumps have been accepted by many utilities and their customers, but they are not considered strictly HDR. Conventional, lowertemperature hydrothermal systems at shallow $(<300 \mathrm{~m})$ depths have been successfully developed in the western United States for non-electrical uses, but HDR systems would not be competitive there under present market conditions. On the other hand, New York state has successfully developed a hydrothermal space-heating and cooling system for a school district near Auburn, which incorporates some features of an HDR system and can serve as a prototype for low-temperature HDR development (Castor, 1988). The competitiveness of HDR energy will ultimately be determined by the price of fossil fuels.

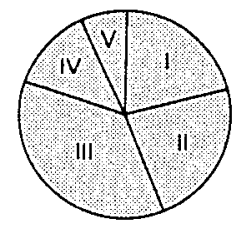

Total GW $=41,609$

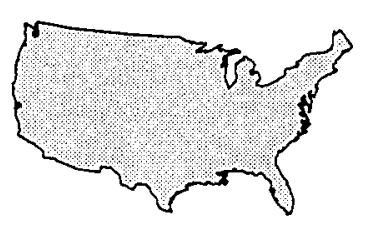

Total United States

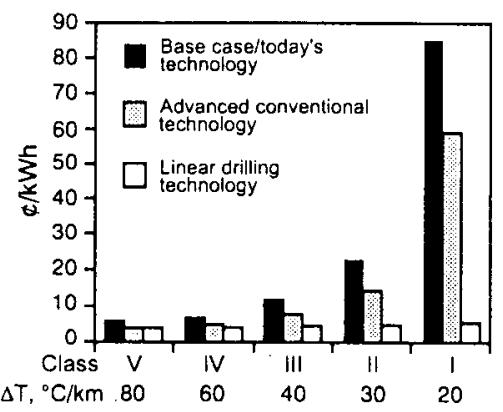

Figure 9. Predicted HDR busbar electricity costs in five resource classes with three levels of technology assumed. The total 41,609 Gigawatts electric $\left(G W_{e}\right)$ is for a 20-year production horizon (see Tester and Herzog, 1990, for details and methodology used).

The economics of HDR have both positive and negative external factors that could influence commercialization. On the plus side, emission controls on carbon dioxide, nitrogen and sulfur oxides, and particulates from fossil-fuel-fired plants will improve HDR's competitiveness, and other provisions of the Clean Air Act (e.g., emission credits) could also help. However, coal and natural gas are in plentiful supply. By far, the biggest economic constraint on HDR 
is risk, both real and perceived. The element of risk makes the economic studies conducted to date uncertain. The risks involved in hydrothermal projects has been largely overcome, and the lessons learned from perfecting that geothermal technology can be applied to the development of HDR.

\section{WHAT ARE THE TECHNOLOGICAL BARRIERS TO HDR?}

Recoverability refers to the ability to extract (recover) thermal energy from a subsurfacerock reservoir in a form useable at the earth's surface. Certain generic questions concerning behavior of the rock reservoir need to be answered by long-term flow tests at Fenton Hill and other sites including:

- Will the reservoir volume increase with time?

-Will impedance to fluid flow decrease or stay the same?

- Are reservoir-volume estimates based on short-term production data accurate?

Depending on the type of heat-recovery model used, the reservoir volume needed for economic production of hot-dry-rock energy could be as large as $0.2 \mathrm{~km}^{3}$ per injection and production well pair (or doublet). There are certain design criteria for an HDR facility (i.e., the values of criteria such as flow rate, fluid temperatures, injection pressure, reservoir impedance, reservoir volume, etc.) that must be attained for economic production of energy from hot-dryrock reservoirs. The design criteria can be reasonably constrained by data from hot-dryrock experiments in the United States and elsewhere (see analyses by Armstead and Tester, 1987; and Garnish and others, 1992;).

Data from flow tests have established a critical relationship between injection pressure and reservoir impedance. Because the injection pressure for long-term production (10-20 years) must be lower than the pressure that causes reservoir growth (and thus high water loss), flow rate is limited by reservoir impedance. An important question is whether reservoir impedance can be low enough, and reservoir volume large enough, to allow high fluid-flow rates and long reservoir life, both of which are critical for commercial production of hot-dryrock energy. A central and as yet unanswered question is whether hot-dry-rock reservoirs can be engineered to meet these design criteria, or whether the earth's natural properties limit the range of working conditions to less than the design goals.

Long fluid-flow paths are necessary to maximize the heat transfer area, but longer paths generally mean higher impedance. Conversely, if impedance is too low, fluid will flow too directly ("short circuit") to the production well. Multiple production wells that operate cyclically in a coordinated manner constitute an enhanced production strategy that needs to be evaluated as HDR evolves.

Although environmental effects from HDR are expected to be easily addressed, induced seismicity could be a serious impediment in some locations (Zoback and Hickman, 1982; Nicholson and Wesson, 1990). Field evidence in the United States, United Kingdom and Japan indicate low seismic risk; however, rockbreakdown pressures in the East may be high because the regional stress regime is predominately compressive. One earthquake associated with HDR development that is felt by the populace could be enough to create negative public reaction

\section{CONCLUSIONS AND RECOMMENDATIONS}

\section{GENERAL CONCLUSIONS}

The general conclusions of the assembled group are implicit in the narrative of the preceding section and in the more detailed summaries of the panel discussions in Appendix D. Unanimity was rarely achieved, as would be expected from free and open discussions of complex and controversial topics, but there was a general consensus on the major issues, 
namely:

1) Hot-dry-rock (HDR) is a developing technology and is potentially the most important component of a national heat-mining strategy.

2) The definition of HDR should be broadened to encompass both the creation of new reservoirs and stimulation of waning or marginally productive hydrothermal systems by hydrofracture.

3) While technical feasibility has been demonstrated at specific sites, the general applicability of HDR has not, and many obstacles must be overcome to demonstrate commercial feasibility.

4) In the present energy market, electrical generation from HDR might be marginally economic at some sites in the eastern United States with high temperature gradients; however, even assuming high reservoir productivity and today's drilling technology, HDR would not generally compete on price alone, even if a commercial-scale plant could be built.

5) A commercial-scale (10-50 $\mathrm{MW}_{\mathrm{e}}$ ) HDR or mixed-fuel (hydrocarbon and geothermal) electrical generating facility is at least 5 years away and probably more like 15 , depending on the levels of public and private support.

6) Low-temperature, direct-use heat-mining (including HDR) may eventually become economic for applications like institutional space-heating and cooling and process heat in much of the eastern United States.

7) Even if HDR heat-mining is to be phased in gradually as an energy option, the market must be conditioned now to accept it as part of long-range planning.

\section{RECOMMENDATIONS}

The recommendations of the various panels and other workshop participants can be conveniently divided into 2 categories: Resource Evaluation and Assessment, and Technology Development. The first category has traditionally been the province of the USGS, particularly as it pertains to hydrothermal systems, while technology development has been funded primarily by DOE and carried out exclusively by the hot-dry-rock project at Los Alamos National Laboratory, with input from a variety of other sources including industry, academia and other federally funded research entities.

While the HDR workshop covered a wide range of issues related to the technology and was responsive to the mandate of Section 2502 of EPACT, a single day did not provide enough time to consider all issues in depth. Thus, the specific recommendations of the workshop fall short of a comprehensive list of actions that might be required to provide policy makers and utilities with sufficient information to fully evaluate HDR as an alternative energy source. This is particularly true of the field of hydrology, which was not covered explicitly in the workshop agenda.

\section{Resource Evaluation and Assessment}

1) Fill in the gaps in heat-flow coverage of the eastern United States to provide a better quantitative basis for resource assessment. Use existing holes where possible, but drill dedicated boreholes in critical localities. This would be accomplished most effectively by a consortium of USGS and university heat-flow researchers.

2) To facilitate estimates of potential reservoir temperatures, assemble a data-base including heat-flow data, reliable deep temperature data from industry sources, and thermal conductivity data. The Geological Society of America's thermal data base assembled at Southern Methodist University and described by Blackwell and others (1991) would be a good starting point.

3) To provide a firm basis for prediction of breakdown pressures, fracture geometry and 
pumping pressure, analyze the existing data on regional stress in terms of its implications for hydraulic fracturing and induced seismicity. Work jointly with the USGS, national laboratories, and university groups and use data from both mining and petroleum sources.

4) Perform in situ stress measurements by hydrofracture in conjunction with boreholes drilled for heat flow and other purposes. These data are needed to establish whether or not suitable reservoirs can be created virtually anywhere. This could best be accomplished through a Cooperative Research and Development Agreement (CRADA) between USGS stress-researchers and segments of the private-sector concerned with drilling and hydrofracturing. CRADA's are specifically mandated by Section 2501 of EPACT.

5) Review and update existing resource assessments to include more information on candidate HDR sites.

6) Inventory water supplies and perform detailed hydrologic studies near candidate HDR sites.

\section{Technology Development}

1) Complete a long-term flow test at Fenton Hill, NM. The site is a well-calibrated laboratory, but its performance has been evaluated for only a very small range of parameters.

2) Drill a second production well at Fenton Hill to test the hypothesis that this will decrease reservoir water loss and increase access to a larger rock volume and thereby facilitate thermal energy recovery at near-commercial rates.

3) Coordinate present efforts to stimulate increased production in existing hydrothermal fields with purely $\mathrm{HDR}$ experiments in recognition of the spectrum of potential heatmining resources.

4) Select an HDR prototype site in the eastern United States.
5) Re-establish formal cooperation among United States, European and Japanese heatmining research projects.

6) Increase Government-industry joint research efforts on advanced drilling technologies with the goal of decreasing the cost of drilling deep wells.

\section{Implementation Strategy}

There was clear agreement among workshop participants that HDR in general, and particularly in the eastern United States, will not be successful as a purely governmentsponsored research effort. Nor can industry be expected to absorb the entire cost of establishing HDR as a credible energy option. The recommendations enumerated above must be implemented in the spirit of partnership among Federal, state and local governments, utilities, power producers and consumers. The approach must be incremental, beginning with the simplest and most successful heat-mining options and progressing to full-scale commercial-sized demonstrations of HDR.

If the eastern prototype HDR plant is designed, constructed and proven successful, utilities can be expected to begin factoring HDR into their electrical generation strategies. In this context, it is important that the resource evaluation studies be carried out in a careful and systematic way. The demonstration plant should be located in the most favorable thermal environment, bearing in mind such market factors as demand and proximity to transmission lines, where the hydrologic and stress conditions also are such as to permit the creation and maintenance of a suitable HDR reservoir.

The collaborative approach to HDR development is mandated in Section 2501 of EPACT, which defines a role for the USGS (in consultation with DOE) in establishing:

"a cooperative Government-private sector program with respect to hot-dry-rock geothermal energy resources on public lands.... and lands managed by the Department of 


\section{Agriculture..."}

"Such program shall include, but shall not be limited to, activities to identify, select and classify those areas throughout the United States that have a high potential for hot-dryrock geothermal energy production and activities to develop and disseminate information regarding the utilization of such areas for hot-dry-rock energy production."

"The Secretary, acting through the United States Geological Survey, may also enter into contracts and cooperative agreements with any public or private entity to provide assistance to any such entity to enable such entity to carry out additional projects with respect to the utilization of hot-dry-rock geothermal energy resources which will further the purposes of this section."

Key representatives of the international community attended the workshop (Appendix B) and all of them stressed the importance of international cooperation in HDR development. In planning HDR research goals for the next decade, a more formal arrangement, including official visits among the various installations, should be considered a critical element.

Finally, passage of Public Law 102-486 presents an opportunity for the formation of a partnership among government, industry, utilities, universities and the public to seek beneficial changes in national energy priorities. 


\section{REFERENCES}

Armstead, H.C.H., and Tester, J.W., 1987. Heat Mining. London: E.F. Spon, 478 pp.

Baria, R., Baumgärtner, J., Gerard, A., and Kappelmeyer, O., 1992. HDR project at Soultz-sous-Forêts: Geothermal Resources Council Trans., 16, pp 387-394.

Blackwell, D.D., and Steele, J.L., 1992. Geothermal Map of North America: Geological Society of America, DNAG Neotectonic Series, scale, 1:5,000,000, 4 sheets.

Blackwell, D.D., Steele, J.L., and Carter, L.S., 1991. Heat flow patterns of the North American Continent; A discussion of the Geothermal Map of North America, in Slemmons, D.B., Zoback, M.D., and Blackwell, D.D., eds., Neotectonics of North America: Boulder, Colorado, Geological Society of America, Decade Map Volume 1, pp 423-436.

Bresee, J.C., (Editor), 1991. European HDR Project at Soultz-sous-Forêts: Geothermal Science and Technology, V3, No.'s 1-4, 308 pp, Philadelphia: Gordon and Breach.

Burns, K.L., Potter, R.M., Zyvoloski, G., 1992. Geothermal Regimes at Clearlake, California: Geothermal Resources Council Trans., 16, pp 135-143.

Castor, T.P., 1988. Hydrothermal Energy Extraction Auburn, New York: Energy Authority Report 883, prepared by Eng, Inc.

Garnish, J., Batchelor, T., and Ledingham, P., 1992. Hot Dry Rock: Fringe Technology or Key Component?: Geothermal Resources Council Trans., 16, pp 403-409.

Nicholson, C., and Wesson, R.L., 1990. Earthquake Hazard Associated with Deep Well Injection - A Report to the U.S. Environmental Protection Agency: U.S. Geological Survey Bulletin 1951, 74 p.

Parker, R.H., (Editor), 1990. Hot Dry Rock Geothermal Energy: Proceedings of Camborne School of Mines International HDR Conference. June 1989, 613 pp, London: Robertson Scientific Publications.

Tester, J.W., 1992. Testimony on Hot Dry Rock Geothermal Energy to the U.S. Congress: Geothermal Resources Council Bull. 21, pp 137-147.

Tester, J.W., and Herzog, H., 1990. Economic Predictions for Heat Mining: A Review and Analysis of Hot Dry Rock (HDR) Geothermal Energy Technology: MIT Energy Laboratory Report, MIT EL 90-001.

Tester, J.W., and Herzog, H., 1991. The Economics of Heat Mining: An Analysis of Design Options and Performance Requirements of Hot Dry Rock (HDR) Geothermal Power Systems: Energy Systems and Policy, 15 pp 33-63.

Yamaguchi, T., Hiwaki, N., Abe, T., and Oikawa, Y., 1992. 90-Day Circulation Test at Hijiori HDR Test Site: Geothermal Resources Council Trans. 16 pp 417-422.

Zoback, M.D., and Hickman, S.H., 1982. In-situ Study of the Physical Mechanisms Controlling Induced Seismicity at Monticello Reservoir, South Carolina: Jour. Geophys, Res, 87, pp 6959-6974. 


\section{APPENDIX A: WORKSHOP PROGRAMS}

\section{EPRI Workshop}

Potential of HDR Resources for the U.S. Electric Utility Industry

January 14, 1993

0800 Registration at Philadelphia Electric Company

0830 Introduction

Representative Peter H. Kostmayer

0850 Concept of Geothermal Energy Mining

Paul Kruger, SGP

Review of American HDR Program

0910 Cumulative Experience of U.S. Program

0930 Current Experience with LTFT at LANL

0950 Next Stages in HDR Technology Developments

1010 Expectations for a Second U.S. Site

1030 Break

LANL

Don Brown

Don Brown

Robert Du Teau

David Duchane

Review of International HDR Programs

1100 Europe Experiences

1120 Japan Experiences

1140 World Prospects

1200 Box Lunch \{with discussion\}

John Garnish, EEC Tsutomu Yamaguchi, NEDO

Paul MacDonald, ETSU

HDR Potential for the Electric Utility Industry

1300 Potential U.S. Resources

1320 Economic Analysis

Current Outlook

1340 Electric Power Potential

1400 Cogeneration

1420 Geothermal Heat Pumps

1440 Break

Needed Infrastructure

1500 Role of Utility

1520 Role of Ind. Power Producers

1540 Role of Government

George Hay, PG\&E

Bill Leedy, CDI

John E. Mock, DOE

1600 Wrap-up

Larry Kellerman, CP

1615 Open Discussion by Participants 


\section{USGS/DOE WOPKShOP \\ Potential of HDR Resources in the Eastern United States \\ January 15, 1993}

istits MORNING SESSION: The Potential Resource tor tot to Chaired by Marianne Guffanti (USGS)

0900 Introductory Remarks: John Sass (USGS)

0915 KEYNOTE ADDRESS:

Heat Flow and Subsurface Temperature of the Eastern U.S.

David D. Blackwell (SMU)

1000 PANEL DISCUSSION on Most Promising Regions/Localities.

Panel: Dave Blackwell, John Costain, Ed Decker, Doug Smith, Will Gosnold, Marianne Guffanti, Grant Heiken, Bill Hinze

\section{BREAK}

1115 PANEL DISCUSSION on "What is Hot-Dry Rock?" Broaden Definition to Include Reservoir Enhancement and Stimulation in Marginally Productive Hydrologic Settings.

Panel: John Garnish, Tsutomu Yamaguchi, John Ziagos, Bob Greider, Dave Duchane, John Sass, Steve Hickman.

1215 BOX LUNCH \{with discussion\}

that AFTERNOON SESSION: Technology and Economics is is it Chaired by Allan Jelacic (DOE)

1330 Introductory Remarks: Allan Jelacic

1345 KEYNOTE ADDRESS:

Potential HDR Market in the Eastern U.S.

Jefferson Tester (MIT)

1430 PANEL DISCUSSION on the Technology of Recoverability Across the Accessible Temperature Range.

Panel: Kevin Rafferty, Susan Petty, Tien Lee, Allan Jelacic, Evan Hughes, Don Brown, Manuel Nathenson.

1530 BREAK

1545 PANEL DISCUSSION on EConomic and Environmental Constraints on $H D R$ in the Eastern U.S.

Panel: Jeff Tester, Howard Herzog, Mike Wright, Chandler Swanberg, Parker Mathusa, Michael Berger, Dave Anderson.

1645 Closing Remarks: Dave Anderson (GRC)

1700 Adjourn 


\section{APPENDIX B: LIST OF ATTENDEES}

Name

Abnee, William Anderson, David Bailey, Bruce Berger, Michael Blackwell, David Briffett, Robert Brown, Donald Bustard, John Calore, James Clelland, Peter Costain, John Darr, George Decker, Edward Donegan, James Dorr, Perle Duchane, David Du Teau, Robert Frantz, Joseph Garnish, John Getraer, Andrew Gosnold, William Greider, Robert Guffanti, Marianne Hay, George Heiken, Grant Herzog, Howard Hickman, Stephen Hinze, William Hughes, Evan Jelacic, Allan Kellerman, Lawrence Kennedy, James Kruger, Paul Lee, Tien Leedy, William MacDonald, Paul Mathusa, Parker Mock, John E. Morris, Ellen Nathenson, Manuel Orlando, Joseph Padovani, Elaine
Affiliation

E. Kentucky Power Co. Geothermal Res. Council (GRC)

AWS Scientific

Los Alamos Natl. Lab. (LANL)

So. Methodist Univ. (SMU)

Los Angeles Dept. Water \& Pwr.

Los Alamos Natl. Lab. (LANL)

Philadelphia Elec.

Public Service Elec. \& Gas

Philadelphia Elec.

Virginia Polytechnic Inst.

Bonneville Pwr. Admin.

Univ. Maine

Niagara Mohawk Pwr. Corp.

Meridian Corp.

Los Alamos Natl. Lab. (LANL)

Los Alamos Natl. Lab. (LANL)

S. A. Holditch \& Assoc.

European Community (CEC), Brussels

Geothermal Pwr. Co.

Univ. North Dakota

Chevron (retired)

U.S. Geological Survey (USGS)

Pacific Gas \& Elec. (PG\&E)

Los Alamos Natl. Lab. (LANL)

Mass. Inst. Tech. (MIT)

U.S. Geological Survey (USGS)

Purdue Univ.

Elec. Pwr. Res. Inst. (EPRI)

U.S. Dept. of Energy (DOE)

Citizens Pwr.

U.S. Govt. Accounting Off. (GAO)

Stanford Univ.

Univ. Cal. Riverside

Constellation Energy

Energy Tech. Support Unit,UKDOE

New York State ERDA

U.S. Dept. of Energy (DOE)

Staff, U.S. Congress

U.S. Geological Survey (USGS)

Consultant, GKCO, Inc.

U.S. Geological Survey (USGS)
Workshop

Attended 1

1, 2

2

2

1,2

1

1,2

1

1

1,2

1, 2

1, 2

2

1, 2

1, 2

1, 2

1, 2

1

1, 2

1, 2

1, 2

2

1, 2

1, 2

1, 2

1, 2

1, 2

1, 2

1, 2

1,2

1

1, 2

1, 2 .

1, 2

1

1

1, 2

1, 2

1,2

1

\footnotetext{
${ }^{1} 1$ - EPRI Workshop Jan. 14, 1993

2 - USGS/DOE Workshop Jan. 15, 1993
} 
Petty, Susan

Rafferty, Kevin

Riehle, James R.

Sass, John H.

Scheffler, Robert

Shulman, Gary

Shumaker, Michael

Smith, Douglas

Stein, Russell

Swanberg, Chandler

Switliski, Len (Leonard)

Tester, J. W.

Wallace, Raymond H., Jr.

Whitelaw, Robert

Wright, P. Michael

Yamaguchi, Tsutomu

Ziagos, John P.

Ziedman, Richard J.
Consultant, S.P. Consulting

Oregon Inst. Tech. / GHC

1,2

U.S. Geological Survey (USGS)

U.S. Geological Survey (USGS)

So. Cal. Edison

Geothermal Pwr. Co.

U.S. Govt. Accounting Off. (GAO)

Univ. Florida

Attorney, Environment Energy

Consultant

Delmarva Pwr.

Mass. Inst. Tech. (MIT)

U.S. Geological Survey (USGS)

Virginia Polytechnic Inst.

Univ. Utah Research Inst.

New Energy Devel. Organ. (NEDO)

Lawrence Livermore Natl Lab (LLNL)

Consultant, R.J. Ziedman \& Assoc.
1, 2

2

1,2

1

1,2

1,2

1, 2

1,2

1,2

1

1,2

1,2

1,2

1,2

1,2

1,2

1,2

${ }^{1} 1$ - EPRI Workshop Jan. 14, 1993

2- USGS/DOE Workshop Jan. 15, 1993 


\title{
APPENDIX C: SUMMARY OF EPRI WORKSHOP
}

\author{
Potential of HDR Resources for the United States \\ Electric Utility Industry
}

The high quality and diversity of the presentations at the EPRI workshop provided a valuable background for the following day's workshop and afforded an excellent opportunity for interaction between the scientists and engineers of the geothermal research community and the business planners of the utility industry. The schedule of presentations is listed in Appendix A. Acronyms associated with the professional affiliations of individual presenters are defined in the list of attendees in Appendix B.

The workshop was opened with an address by former Representative Peter H. Kostmayer, who was one of the sponsors of EPACT and a key proponent of HDR technology development. Rep. Kostmayer opened by stating that only $1.5 \%$ of DOE's energy research budget is spent on alternative energy resources. He also stated that United States expenditures on HDR are small in comparison to Japan and the European Community, and that the long-term flow test at Fenton Hill needs to be adequately funded, if satisfactory progress is to be made on making HDR commercially attractive. A lively discussion followed in which such topics as international cooperation and the time-line for commercialization of HDR ( 5 years to 20 years, depending on funding levels and assumptions).

Paul Kruger (Stanford) began the technical session with a discussion of the concept of heat-mining and made the point that much of the resistance to incorporating it into energy strategies arises from unfamiliarity with the concept and a view of geothermal as an exotic technology applicable in only a few fortunate sites in the American West. He asserted that the mining analogy is more appropriate for assessing the available resource than the liquid extraction approach (there's much more heat in the rocks than in the pore fluids) and that all hydrothermal systems will become HDR candidates with fluid depletion. Reservoir stimulation by injection of produced fluids and condensates, as well as injection of ground water into the reservoir, constitute alternative HDR production schemes.

The next series of talks was given by Los Alamos National Laboratory (LANL) personnel associated with the Fenton Hill HDR project. The LANL researchers covered much of the material provided in the previous section and David Duchane, HDR Program manager, gave some background on the proposal for a second HDR site. The proposed project, located at Clearlake, CA, would most likely be in the form of a "cooperative research and development agreement" (CRADA) with industry. It is further proposed, with an accelerated funding schedule, to bring a "commercial" HDR or dual-fuel (geothermal/gas) plant on line within 5 years. The feasibility of this schedule was a matter of controversy, centered on the degree to which the Fenton Hill experience can be scaled-up by a factor of 10 or more and transferred to a different geologic and stress environment within the 5 year time-frame, regardless of funding level.

The review of international programs by the next three speakers provided a useful overview of activities overseas. The bottom line here is, for somewhat comparable dollars spent (to the total on foreign projects), the LANL HDR project is probably the farthest along. Although there is great diversity in geologic settings, there is much in common with the various projects, particularly with respect to such parameters as total flow rates and back-pressures and the tendency of the rocks to fail by slip along pre-existing joints and fractures, rather than fracturing in a direction consistent with what would be predicted for homogeneous, isotropic rock in the ambient stress field. A 
common failing of all HDR projects to date is that the reservoir impedance is 5 to 10 times higher than that required for optimum performance.

The lunch-time discussion centered on the credibility of both LANL's 5-year time-line and the leap from the rather modest achievements at Fenton Hill (sustained $4 \mathrm{MW}$ thermal for 16 weeks) to a plant that would produce tens of megawatts-electric for less than $\$ 0.10$ (1990) per $\mathrm{kWh}$ (exclusive of capital costs). John Garnish of the EEC stated that a more realistic time-line would be 15 to 20 years. Many of the participants then engaged in a discussion of how much research is enough and what constitutes the best strategy for getting a second HDR site (this one of commercial scale) on line.

The afternoon session began with an analysis by John Sass and Marianne Guffanti (USGS) of the potential HDR resource base of the United States. They pointed out that although the resource base for HDR was undoubtedly larger than the hydrothermal one, it could not be defined quantitatively until the nature of the resource was better understood and the commercial viability of the technology was established. Assessment of the HDR accessible resource base should start with review of previous geothermal assessments. As with hydrothermal systems, the West probably has higher potential than the East, based on higher temperatures at accessible depths, but trade-offs among applications, available water, environmental concerns and population density could make a number of regions and localities in the East attractive exploration targets. The ideal target in the eastern United States and Great Plains is one in which heat flow from the basement rocks is higher than average (caused either by heat generation from highly radioactive rocks or a plume of hot water driven upwards from greater depths by convection) and whose rocks are blanketed by one or more kilometers of sedimentary material having low thermal conductivity.

Jefferson Tester (MIT) gave an update of his and colleague Howard Herzog's economic analysis of the costs associated with developing an HDR reservoir using different assumptions for temperature gradients and drilling and hydraulic-fracturing costs. The base case for this analysis comes close to being competitive with conventional forms of energy, particularly in areas of high thermal gradients $\left(60^{\circ} \mathrm{C} / \mathrm{km}\right.$ or greater $)$. The case for competitiveness rests heavily on dramatic improvements in drilling technology and, to a lesser extent, on improvements in stimulation and extraction technology and "externalities" (mainly environmental constraints and associated costs, the volatile politics of petroleum and the like).

George Darr, Bonneville Power Administration (BPA), explained that his agency has developed a policy of diversifying its energy sources, including hydrothermal development. BPA has negotiated cooperative agreements with independent power producers at three hydrothermal locations within its area of operation: the Newberry caldera and Vale in Oregon and at Glass Mountain in northern California. The policy has been dictated primarily by the limits of hydropower and the necessity to hedge against interruptions in petroleum supplies and unanticipated cost increases for gas and other fuels. Even for the hydrothermal projects, the process of bringing power on line is protracted and complicated. It is anticipated that bringing $\mathrm{HDR}$ into the mix will be even tougher.

Joseph Orlando (GKCO Inc.) spoke about cogeneration (producing electricity and heat in the same operation). He did not know how cogeneration could be applied to HDR. Cogeneration can only be made cost-effective under present rules by applying it to large-scale facilities. The projected optimum HDR sites would generate 20 to $50 \mathrm{MW}$. He regards 120 to $150 \mathrm{MW}$ facilities as small! Utilities and independent power producers (IPPs) are risk-averse, bottom-line oriented and unwilling to spend significant amounts of money on external benefits like community goodwill. $\mathrm{He}$ finds estimates of as little as 10 years for reservoir life very risky when power contracts are being signed for 30 years or longer. Even lower drilling costs won't make it economic; the rules must be changed. 
William "Conn" Abnee of the Eastern Kentucky Power Cooperative (EKPC) provided a success story in "demand-side management" (DSM) with particular reference to geothermal heat-pump technology. Although geothermal heat pumps are not, strictly speaking, in the realm of HDR, this popular and successful application of low-temperature direct-use geothermal technology provides some lessons and a starting point for familiarizing utilities with geothermal energy. Ground source heat pumps provide a $66 \%$ increase in efficiency over conventional air-source heat pumps, with a consequent saving of $30 \%$ in heating and cooling costs by the consumer. The benefit for the utility is to decrease the new generating capacity that it has to provide. Also provided is a highly beneficial environmental impact for the utility. Thus, several utilities, including EKPC, subsidize the installation of geothermal heat pumps in the amount of $\$ 1,000$ per well and $\$ 300$ per ton of heating and cooling capacity. Public acceptance has been overwhelmingly favorable with a satisfaction rate in questionnaires of $\mathbf{9 7 \%}$.

George Hay, a geothermal specialist with Pacific Gas and Electric (PG\&E), the world's largest single user of geothermal power, reviewed the status of attempts to improve the productivity of The Geysers Geothermal Field and the long-term goals of PG\&E with respect to fuel diversification. PG\&E is working with EPRI on designing the next generation of geothermal projects, which include gas-geothermal hybrid plants to improve efficiency. PG\&E's concerns with HDR include the necessity to prove commercial viability, the degree to which the Federal government is willing to support R\&D and the uncertainties remaining after the Fenton Hill experiment.

Bill Leedy (Constellation Energy Development Inc) stressed the long-term nature of power contracts (now reaching 40 to 50 years) with the accompanying requirements for rapid capital buydowns and well characterized, long-lived reservoirs. The more-rapid-than-anticipated drawdown at The Geysers has raised concerns as to the accuracy of estimates for reservoir sustainability. The term "risk-averse" came up often. Results of the Fenton Hill experiment apparently have not favorably impressed bankers, utilities and operators. For HDR to succeed, risks associated with reservoir development must be well characterized, and an appropriate riskreward balance established.

John E. Mock (DOE) reviewed the historical role of the Federal government as a partner of industry in the development of alternative energy. This includes basic research, demonstration projects, loan-guarantee programs, cost-shared projects, joint ventures and technology transfer. He reviewed the implications of EPACT for future research directions, particularly as it affects renewable energy sources (especially geothermal research), highlighting the continuation of research in DOE's Geothermal Division and the Office of Basic Energy Research (BES); the encouragement of the expansion of the use of geothermal heat pumps and the new role of the USGS in HDR research. Without government-industry cooperation in R\&D and government as a customer (initially), the transition of HDR from a research success to a commercial venture is not likely to take place. This requirement is dictated by the fundamental paradox between present uncertainties in the commercial application of HDR and the natural risk-averseness and long-term planning strategies of both utilities and independent power producers (IPPs). Of particular importance is the development of new, lower-cost drilling technology. The goal is linear, rather than exponential, increases in drilling costs with depth.

Finally, Larry Kellerman (Citizens Power and Light Corporation) provided a philosophical discourse on conditioning the market to accept HDR. "Even if you do have a better mouse-trap, the world (and certainly the mouse) won't necessarily beat a path to your door." Kellerman stressed that HDR research should be customer-oriented, and that the wide acceptance of geothermal heat pumps is a good start in conditioning the market. He defined a "risk chain" that includes government, IPPs and utilities. Nothing happens that isn't initiated by the utilities, but others in 
the chain must accept some of the risk. The utilities are now making planning decisions that will determine the course of energy development for the first quarter of the next century. HDR must become part of that planning now. 


\section{APPENDIX D: DETAILED SUMMARIES OF USGS/DOE PANEL DISCUSSIONS}

No verbatim records of the panel discussions were made; however, a reporter from the audience was assigned to each panel, and independent sets of notes were made by others, both in the audience and panels. Finally, the panel chairs were given the opportunity of editing the summaries to remove any inconsistencies or add anything that may have been omitted by the reporters. 


\section{PANEL DISCUSSION 1}

\section{Most Promising Regions and Localities for HDR in the Eastern United States}

\section{Panel Members}

William Hinze (Chair), Purdue University

David Blackwell, Southern Methodist University

John Costain, Virginia Polytechnic Institute

Edward Decker, University of Maine (Orono)

Douglas Smith, University of Florida

William Gosnold, University of North Dakota

Marianne Guffanti, U.S. Geological Survey

Grant Heiken, Los Alamos National Laboratory

\section{$\underline{\text { Panel Discussions }}$}

William Hinze (chair) opened the discussion with some introductory remarks and established a format in which each panel member gave a brief statement, followed by about 15 minutes of open discussion including members of the audience. Identification of areas with potential HDR resources is based on heat-flow data, depth to appropriate crystalline reservoir rocks and the physical and chemical properties of those reservoir rocks. Data sets include regional geophysical surveys to evaluate the depth, shape and extent of candidate reservoir rocks, and widely spaced thermal, hydrologic and other borehole data, which are crucial to an understanding of the heat sources. These data, although sparse, can be used to identify some general areas of interest in the eastern United States, which for purposes of this report is defined as the conterminous United States, east of Longitude $105^{\circ} \mathrm{W}$.

The "average" heat flow for the eastern United States is 55 to $60 \mathrm{~mW} \mathrm{~m}^{-2}$ (milliwatts per square meter, or in perhaps a more easily understood unit for energy purposes, kilowatts per square kilometer). This average is, however, misleading, because the crustal rocks are physically and compositionally variable and heat flow varies from place to place, depending on geologic conditions. The most promising crustal heat sources are granitic intrusive rocks (particularly those that are rich in uranium, thorium and potassium), which generate heat by radioactive decay. The ideal situation for a thermal anomaly in these older rocks is a thick granitic pluton overlain by thermally insulating sedimentary rocks one-to-several kilometers in thickness.

A preliminary evaluation of the accessible HDR resources in the East was presented in the keynote address by panelist David Blackwell. The existing data are sparse; for example, there are no acceptable heat-flow measurements within the state of Kentucky (notwithstanding which, that state is benefiting greatly from the aggressive, utility-subsidized deployment of geothermal heat pumps). No thermal anomalies in the East are attributable to young-to-contemporary volcanic or other igneous activity; most are in areas of relatively high heat flow, blanketed by sediments of low thermal conductivity, or above areas of upflowing water, heated deeper in the crust. Temperatures of potential heat-mining sites would rarely exceed $150^{\circ} \mathrm{C}$ to depths of $4 \mathrm{~km}$ in this region.

Based upon the existing incomplete data set, the most promising areas of interest (top of crystalline basement at depths of less than $4 \mathrm{~km}$ ) are in western New York, in Pennsylvania, along the Delmarva Peninsula of Delaware, Maryland and Virginia, northern Nebraska and southern 
South Dakota, along the Wisconsin-Illinois border and in northern Louisiana. The areas of interest expand considerably, if the target temperatures are lower $\left(60\right.$ to $\left.80^{\circ} \mathrm{C}\right)$. John Costain reviewed the state of knowledge in the Valley and Ridge province, Appalachians and Atlantic coastal plain, based on earlier, DOE-sponsored work. The coastal plain, from the Appalachian Mountains to the coast, overlies a chain of buried, radioactive, heat-producing granitic bodies that can be located using surface-based geophysical surveys (gravity and magnetic measurements), and then verified by core drilling. One of these thermal anomalies, located at Smith Point, VA had a temperature of $67^{\circ} \mathrm{C}$ at a depth of $1.6 \mathrm{~km}$.

Edward Decker reviewed the thermal regime of New England, in general, and the White Mountains of Maine and New Hampshire, in particular. The latter consist mainly of overlapping granitic intrusions with anomalously high radiogenic-heat production. Although heat flows are anomalously high (up to $80 \mathrm{~mW} \mathrm{~m}^{-2}$ ) by eastern United States standards, temperatures at drillable depths are not very high because of the lack of an insulating sedimentary cover. With present technology and the foreseeable market conditions, geothermal energy applications are probably limited to geothermal heat pumps and other direct-use applications. The White mountains are structurally complex and individual granitic bodies are more likely to be relatively shallow, funnelshaped bodies, rather than cylindrical masses extending to great depths. Thus, the relatively high temperature gradients observed near the surface are likely to decline with increasing depth.

A summary of heat flow in the Great Plains was delivered by William Gosnold. Heat flow is variable, but generally moderate. There are some areas, however, where gravitationally driven convection produces anomalously high heat flow, which results in temperatures of about $100{ }^{\circ} \mathrm{C}$ at depths of 2 to $3 \mathrm{~km}$. One such region occurs along the border between Nebraska and South Dakota within the Dakota Sandstone aquifer. Gosnold emphasized that HDR applications do not necessarily require crystalline basement rock. Some sedimentary formations, like carbonate rocks and well-consolidated sandstones, would be suitable for the same well-stimulation hydrofracturing techniques used in the petroleum industry. Ancient, elongated basins (rifts) cross the midcontinental region from north to south. Buried by younger sedimentary rocks, the structure and composition of these basins may provide thermal sources that could be tapped with HDR technology.

Douglas Smith has done most of his eastern United States thermal research in Mississippi, Alabama and Florida, where heat flow and temperature gradients are quite low. He believes there is no potential for electrical generation within that region, but felt that there could be some potential for space-heating and cooling applications in the heavily-populated areas of north Florida. Data are sparse, but heat flow along the Gulf coast appears to be low. There may be some possible exceptions in Arkansas, where there are indications of heat flow as high as $70 \mathrm{~mW} \mathrm{~m}^{-2}$. Another exceptional area is the Monroe Platform in Louisiana, where geothermal gradients of 30 to 40 ${ }^{\circ} \mathrm{C} / \mathrm{km}$ have been observed.

The panel concluded that, although existing data can be used to identify some areas of elevated heat flow and the nature of potential reservoir rocks within these anomalies, these data are sparse and of questionable quality in many instances. Systematic studies of heat flow, hydrology, geology and stress are required on both regional and local scales to provide a data base sufficient for evaluation and assessment of potential HDR resources in the eastern United States. This data base should be obtained, to the extent possible, using "holes of opportunity" drilled by industry and government for other purposes. It will probably be necessary, however, to drill dedicated core holes in areas where no data are available and to outline the most promising prospects. 


\section{PANEL DISCUSSION 2}

\section{What is Hot-Dry-Rock (HDR)?}

\section{Panel Members}

John Garnish (Chair), European Economic Community

Tsutomo Yamaguchi, New Energy Development Organization (NEDO) (Japan)

John Ziagos, Lawrence Livermore National Laboratory

Robert Greider, Chevron Geothermal (Retired)

David Duchane, Los Alamos National Laboratory

John Sass, U.S. Geological Survey

Stephen Hickman, U.S. Geological Survey

\section{Panel Discussions}

The term "hot-dry-rock" was coined by physicists and originally had a very restricted, specific meaning; viz. completely impermeable crystalline basement at a temperature that can provide useful amounts of energy. The rationale for assembling this panel was, in part, to examine the directions that HDR has taken since it was originally defined and to assess the desirability of broadening the definition to include much of what has come to be termed "heat-mining" (Armstead and Tester, 1987). The chair began the discussion by stating that despite the fact that target parameters for commercial HDR are well known, very little progress has been made toward commercialization during the past decade. The greatest technical challenge appears to be achieving low enough impedance within the artificially created reservoir. Ambient stresses and nature of existing fracture systems may limit the extent to which low impedance can be engineered. An area of research that has largely been neglected is the study of naturally occurring fractures to identify stress-fracture configurations that yield optimum impedances.

Tsutomo Yamaguchi provided some insight into the status of Japanese HDR research. NEDO's program has 3 basic elements, all are aimed ultimately at enhancement of existing reservoirs rather than creation of new ones. The elements are: 1) development of hydraulic fracturing technology; 2) interaction of natural and artificial fractures; and, 3) monitoring fracture widening and extension as part of reservoir enhancement. Yamaguchi's presentation produced discussion of the difficulty of obtaining fractures in the desired direction in existing reservoirs. Once again, the ambient stress field and pre-existing zones of weakness tend to determine the type and direction of induced fractures.

Stephen Hickman presented a map of the eastern United States showing that the predominant stress mode in the East is compressive. In contrast to extensional regimes, where the least principal horizontal stress can be lower than hydrostatic, it is high in a compressive regime. This implies the need for high pumping pressures to achieve fracturing with attendant engineering problems and cost considerations. A LANL engineer pointed out that the pumping pressures experienced at Fenton Hill were always lower than theoretical and that creation of the reservoir altered the local stress field in a manner that made regional stress relatively unimportant. This prompted further discussion of trade-offs between pumping pressure and water loss, and whether or not microseismicity within the reservoir is actually mapping growth of fractures and, therefore, the reservoir. It was clear from this discussion that much research remains to be done on the relationship among ambient stress field, breakdown pressure, fracture-growth and, ultimately, reservoir productivity. 
A market approach to resource definition was provided by Robert Greider, formerly with Chevron Geothermal; he gave a case history of the Heber field in the Imperial Valley of California, which is in the "warm-wet-rock" part of the heat-mining spectrum. His presentation emphasized the verities of any scheme to tap the Earth's thermal energy; that is, the facts necessary to define the risk the investor is being asked to assume. These include the type of "fuel", its cost, the size of the reservoir and the minimum-certain reservoir life. He stated that the production-injection well configuration used at Heber resulted in a significant decline in production temperature of the field within a year of beginning injection. To sweep a substantial fraction of heat from the rock requires careful attention to the design of both production and injection wells. John Ziagos pointed out significant differences between well configurations at Heber and the nearby East Mesa power plant, which is also a binary-fluid plant. At Heber, the injection wells are at the edges of the lease, ringing the production wells, whereas the two types of wells are interspersed at East Mesa. Apart from semantic differences, the Imperial Valley sandstone reservoirs are distinguished from what are usually termed HDR reservoirs by the large surface area available for heat transfer from rock to fluid. Thus, sweeping heat from "sand-piles" should be more efficient and require fewer circuits of fluid to accomplish.

The above discussion prompted questions on how broadly HDR should be interpreted. David Duchane felt that if research funds are fixed, a broader definition of HDR would stretch funding even more thinly. The panel kept returning to Jefferson Tester's theme of "heat-mining" and questioning the relevance of an explicit definition for HDR.

At this point, the chair returned the discussion to the panel theme and pointed out that the original definition of HDR had been amended (by him among others) to include a wide range of reservoir stimulation procedures. A participant asked whether a patent exists on the term "hotdry-rock". The original patent has expired, Chevron holds a patent on the "heat-sweeping" concept, but it is not being enforced.

John Sass stated that "hot" and "dry" are very explicit terms and that considerable confusion exists among both the public and non-specialist energy communities over the terminology when it is applied to situations that are neither. One of the audience participants, an attorney specializing in energy matters, suggested different definitions based on geographical factors. For instance, water for creating and maintaining HDR reservoirs would be much more plentiful in the East than in the West. Substantial water losses in an eastern HDR reservoir could be quite acceptable, whereas, it could be a limiting factor in the West.

The panel adjourned without reaching consensus on the definition of HDR. The consensus was that HDR is an imprecise term, and that the broader terminology of heat-mining should be stressed, when discussing methods for the extraction of geothermal energy. 


\section{PANEL DISCUSSION 3}

\section{Technology of Recoverability Across the Accessible Temperature Range}

Panel Members

Manuel Nathenson (Chair), U.S. Geological Survey

Don Brown, Los Alamos National Laboratories

Evan Hughes, Electric Power Research Institute

Allan Jelacic, U.S. Department of Energy

Tien-Chang Lee, University of California at Riverside

Susan Petty, Susan Petty Consulting

Kevin Rafferty, Oregon Institute of Technology

Introduction

Allan Jelacic, a former DOE Program Manager for HDR, gave a brief review of the accomplishments and shortcomings of the Fenton Hill program. He covered much of the subject matter found in Section II of this report and added some personal observations and opinions. Total expenditures on the Fenton Hill project between 1973 and the end of 1992 were $\$ 175 \mathrm{M}$. He feels that results to date are promising and that technical feasibility has been demonstrated, but many obstacles to commercial development remain. Increased funding for a period of several years would allow completion of the research at Fenton Hill, before shutting down the facility. Even with accelerated funding, the time necessary for demonstrating commercial viability is projected to be 10 to 15 years.

\section{Panel Discussions}

The technology of recoverability refers to the ability to extract (recover) thermal energy from a subsurface-rock reservoir in a form usable at the Earth's surface. To introduce the concept of recoverability, the chair presented some questions concerning rock- reservoir behavior that must be answered by the long-term flow test at the Fenton Hill site: Will the reservoir volume increase with time? Will impedance to fluid flow decrease or stay the same? Will reservoir-volume estimates match those from short-term production data? Depending upon the heat-recovery model used, the reservoir volume needed for economic production of hot-dry-rock energy could be as large as $0.2 \mathrm{~km}^{3}$. Manuel Nathenson then analyzed production of hot-dry-rock geothermal energy in terms of "design goals" -- i.e., the values of parameters such as flow rate, injection pressure, reservoir impedance, reservoir volume, etc., that must be attained in order to economically produce energy from hot-dry-rock reservoirs. The design goals can be reasonably constrained by data from the United States and international hot- dry-rock experiments.

Manuel Nathenson pointed out that data from flow tests established a critical relationship between injection pressure and reservoir impedance (the latter being the difference between pressure applied at the injection well and pressure maintained at the production well, divided by the flow rate of water exiting the production well). Because the injection pressure for long-term production (10 to 20 years) must be less than the pressure that causes reservoir growth (and thus high water loss), flow rate is limited by reservoir impedance. An important question is whether reservoir impedance can be small enough and reservoir volume large enough to allow high fluid-flow rates and long reservoir life, which are critical for commercial feasibility of hot-dry-rock energy. Manuel Nathenson stated that the relation between deep-rock properties and reservoir behavior is poorly 
understood. He posed a fundamental question: Can hot-dry-rock reservoirs be constructed to required design specifications or do the Earth's natural properties limit the range of working conditions to less than the design goals?

Susan Petty commented on the problem of lesser heat-transfer area with lower impedance; she pointed out that long fluid-flow paths are necessary to maximize heat-transfer area, but longer paths generally increase impedance. Don Brown mentioned that the process of "huff-and-puff" has been observed at Fenton Hill -- a well that is shut-in for several hours initially produces strongly when reopened. David Duchane suggested that this phenomenon might be adapted to multiple production wells that operate cyclically in a coordinated manner.

Paul Kruger discussed fluid residence time as a function of fluid flow rate and noted that, if impedance is too low, the fluid will flow too directly ("short circuit") to the production well. Susan Petty suggested that it is better to flow slowly at small pressure drops. Dave Duchane commented that the difference between injection and production pressures can be lowered, if the reservoir is kept highly pressurized ("blown up like a balloon"). He also stated that water loss likely will be higher at higher flow rates. Don Brown suggested drilling a second production well at Fenton Hill in order to remove heat from more of the fractured reservoir by tapping into a high-pressure zone opposite the existing production well. Bob Greider, the chair of the HDR Program Development Council, reiterated the guidance for the long-term flow test at Fenton Hill: hold flow just below the seismic limit and operate the production well continuously during the flow test.

Don Brown then showed several figures of reservoir-fracture patterns and emphasized the importance of defining reservoir-region by stages during a flow test. An important conclusion of the Fenton Hill experiments is that most reservoir fractures are not new, but pre-existing ones opened by hydraulic fracturing. Currently, reservoir volume is determined by mapping seismicity induced by pressurized fluid-flow through rock fractures. Several participants commented on ways to better define fracture regions. Don Brown explained that, at Fenton Hill, the seismically defined reservoir volume increased proportionally with the volume of fluid pumped during hydraulic fracturing and suggested that twice as much reservoir volume could have been created, if twice as much fluid had been pumped. However, it is not clear what part of that larger volume could be accessed by fluid-flow for heat removal.

The panel discussion closed with ideas on recoverability in the eastern United States for nonelectrical uses. Kevin Rafferty spoke of OIT's experience in developing conventional, lowertemperature hydrothermal systems at shallow $(<300 \mathrm{~m})$ depths in the western United States for non-electrical uses. He was skeptical that hot-dry-rock systems would be competitive. He also noted that a hot-dry-rock facility for direct-use would be much larger than a conventional hydrothermal facility for direct-use. A participant mentioned a favorable economic model for direct-use of hot-dry-rock energy and noted that the price of fossil fuels strongly affects the competitiveness of hot-dry-rock energy. As noted by Susan Petty, a large, direct-use HDR facility would need to be very close to end-users of the thermal energy, because of heat losses when thermal fluids are transported in pipes. An audience member mentioned that utilities must know two fundamental aspects of a hot-dry-rock project: (1) the cost of recovering heat from the reservoir, and (2) the total amount of the resource (heat) that can be recovered. 


\section{PANEL DISCUSSION 4}

\section{Economic and Environmental Constraints on HDR in the Eastern United States}

\section{$\underline{\text { Panel Members }}$}

David Anderson (Chair), Geothermal Resources Council

Jefferson Tester, Massachusetts Institute of Technology

Howard Herzog, Massachusetts Institute of Technology

P. Michael Wright, University of Utah Research Institute

Chandler Swanberg, Geothermal Energy Consultant

Parker Mathusa, New York State Energy Research \& Development Agency

Michael Berger, Los Alamos National Laboratory

\section{$\underline{\text { Panel Discussions }}$}

The panel on economic and environmental constraints provided a positive outlook on the potential for HDR to have an impact on future energy markets. The chair recapped key points of the day's discussions. In particular, he noted that future HDR projects must involve multi-well systems for efficient pressure maintenance and to minimize water losses. A demonstration of HDR technology requires substantial funds, and industry cannot carry out such a project without government support. He called for industry and government to work together to develop the technology. In particular, improvements in drilling technology would be essential, if HDR were to become economic in the East.

Howard Herzog presented some economic analyses to compare the costs of power generation versus direct-uses from HDR in the eastern United States. Given a typical geothermal gradient (i.e., 30 ${ }^{\circ} \mathrm{C} / \mathrm{km}$ ) in the East, the MIT model predicts electricity costs of 25 to 30 cents $/ \mathrm{kWh}$, or about 5 to 10 times higher than the cost of base-load power prices. However, the model indicates heat for directuses could be produced from HDR at 1.5 to 2 times current value. He noted that geothermal heat pumps could provide an excellent psychological bridge to help gain public acceptance for HDR, even though the two technologies shared few common problems. Herzog stated that he had examined four other potential sources of energy supply in the eastern United States during the next century. These included nuclear energy, fusion, solar energy, and biomass. In his opinion, all of these alternatives presented significant problems, none of which are shared by HDR. He noted that HDR offers the nation the only large, ubiquitous, non-carbon energy source, and these facts alone made a compelling case for continued technology development.

As a followup to his keynote address, Jefferson Tester elaborated on his point that drilling costs were the largest single impairment to the cost effectiveness of HDR technology. The challenge was to develop drilling technology where costs increase linearly, rather than exponentially, with depth. In his view, the key to achieving such technological breakthrough is to eliminate wear on the cutting head by avoiding direct contact with the rock. He cited earlier experiments with flame-jet drilling that works on the principal of thermal spallation. A fuel oil-compressed air (or oxygen) mixture is used to produce a hot, supersonic flame, which causes the rock to spall. Combustion gases carry cuttings away from the rock face and up the drill hole. In one test using a flame jet, a simple, truck-mounted rig drilled an 8 -inch diameter hole $300 \mathrm{~m}$ deep into the Conway granite of New Hampshire. During the test, penetration rates reached as high as 100 feet per hour. Tester suggested that, with more development, this technology could hold the key to achieving linear 
drilling costs with depth.

Perhaps the most optimistic view of the future of HDR was given by Chandler Swanberg. He suggested that HDR was much closer to commercial reality than the HDR community thinks. He quoted the old business adage, "good enough is excellent", as an argument to market HDR now and work out the "bugs" later. In his opinion, HDR is at that stage today; it is time to proceed with development. He stated that the data base required to define the resource is already in place. He noted, for example, that two large areas identified as prospects by earlier speakers had been highlighted by a geochemical survey he had conducted 15 years earlier. The various existing data bases should be combined to find the best targets that coincide with the service areas of utilities in need of new generating capacity. The HDR power project should be offered to the utilities on a risk-free basis, with financial backing from professional risk-takers. Swanberg argued that, although we do not have all the answers, we have enough of them. We should stop saying commercialization is 20 years away and "go for it".

Michael Wright maintained the optimism, while pointing out some areas of concern. He saw no environmental effects from HDR that could not be addressed, but cautioned about induced seismicity. In his opinion, just one felt earthquake associated with HDR development could be enough to shut down a project. The economics of HDR have both positive and negative external factors that could influence commercialization. On the plus side, emission controls on carbon dioxide will improve HDR's competitiveness, and other provisions of the Clean Air Act (e.g., emission credits) should also help. But coal and natural gas are in plentiful supply. By far, the most important economic constraint on HDR is risk. The element of risk makes the economic studies completed to date unrealistic. The risk involved in hydrothermal projects has been largely overcome and could serve as a learning example. However, risk is the main reason why, at least for now, government should remain actively involved in HDR technology development. Wright pointed out that a large data base exists for fossil, hydrothermal systems that has been exploited for mineral resources. There is much to learn from these complex systems and advantage should be taken of what mining geologists know about fracture systems and their behavior.

A perspective on HDR development in the East was offered by Parker Mathusa from the New York State ERDA. He pointed out that a low-enthalpy hydrothermal system is operating today in upstate New York and the State is enthusiastic about HDR prospects. Several sites have been identified and the State is ready to consider a site in Allegany County for a research and development project. Mathusa stated that ERDA is prepared to invest as much as $\$ 5 \mathrm{M}$ in a costsharing venture with industry and the Federal government to make the project a reality.

The session closed with further words of encouragement from Michael Berger, who was substituting for Charryl Berger. He had been involved in the HDR Program at LANL for more than ten years, but regrettably the budget had consistently declined during that period. $\mathrm{He}$ applauded LANL for its perseverance in nurturing the technology. And since the technology's potential was too great to ignore, he expressed confidence that the Federal government would restore the HDR Program to a funding level sufficient to demonstrate the technology at Fenton Hill and elsewhere. 


\section{APPENDIX E}

\section{Reports of the Los Alamos Hot-Dry-Rock Exploration and Site Assessment Team and Subcontractors, 1980-1986: Midcontinent and Eastern United States}

1. Goff, F. and Decker, E.R., 1983. Candidate Sites for Future Hot Dry Rock Developments in the United States. Jour. Volcanol. Geotherm. Res. 15, pp 187-221. (Also, Los Alamos Nat'l Lab. Rept. LA-9625-HDR, 39 p., 1982).

* Features White Mountain Batholith, New Hampshire HDR Site and general characteristics of HDR sites.

2. Heiken, G., Goff, F., and Cremer, G., 1982. Hot Dry Rock Geothermal Resource 1980. Los Alamos Nat'l. Lab. Rept. LA-9295-HDR, 113 p.

* Features HDR potential in all sub-areas of the USA.

3. Goff, F., Laughlin, A., Aldrich, J., Ander, M., Arney, B., Decker, E., Gardner, J., Heiken, G., Kron, A., LaDelfe, C., Pettitt, R., and Shannon, S., 1981. Hot Dry Rock Geothermal Prospects, 1981. Geotherm. Res. Counc. Trans. 5, pp 173-176.

4. Kron, A., and Heiken, G., 1980. Geothermal Gradient Map of the Conterminous United States. Los Alamos Nat'l. Lab. Rept. LA-8476-MAP, 1 sheet (color), 1:5,000,000.

5. Kron, A. and Stix, J., 1982. Geothermal Gradient Map of the United States exclusive of Alaska and Hawaii. NOAA/NGDC, Boulder, CO, 2 sheets (color), 1:2,500,000.

6. Aldrich, M.J., Laughlin, A.W., and Gambill, D.T., 1981. Geothermal Resource Base of the World: A Revision of the Electric Power Research Institutes' Estimate. Los Alamos Nat'l. Lab. Rept. LA-8801-MS, 59 p.

7. Aiken, C.V. and Ander, M.E., 1981. A regional strategy for geothermal exploration with emphasis on gravity and magnetotellurics. Jour. Volcanol. Geotherm. Res. 9, pp 1-27.

8. Davis, S.N. (ed.), 1981. Workshop on Hydrology of Crystalline Basement Rocks. Los Alamos Nat'l. Lab. Rept. LA-8912-C, 63 p.

9. Sinha, A.K., Costain, J.K., and Glover, L., 1979. Distribution and Analysis of 300 m.y. old Granites as a Potential Geothermal Resource. Unpub. Rept. Los Alamos Nat'l. Lab., 27 p.

10. Heiken, G., Ander, M., and Shankland, T., 1983. Workshop on exploration for hot dry rock geothermal systems. Los Alamos Report LA-9697-C, 88 p.

\section{Site Specific}

1. Jaupart, C., Mann, J.R., and Simmons, G., 1982. A Detailed Study of the Distribution of Heat Flow and Radioactivity in New Hampshire (USA). Earth Planet. Sci. Lett. 59, pp 267-287.

2. Warren, N., 1979. Rock Physics Characterization of Conway Granite from a DOE Borehole, Conway, New Hampshire. Los Alamos Nat'l. Lab. Rept. LA-8102-MS, 51 p. 
3. Hodge, D.S., DeRito, R., Hilfiker, K., Morgan, P. and Swanberg, C. A., 1981. Investigations of Low-temperature Geothermal Potential in New York State. Los Alamos Nat'l Lab. Rept. LA-8960-MS, $74 \mathrm{p}$.

4. Eckstein, Y., Heimlich, R.A., Palmer, D.F., and Shannon, S.S., 1982. Geothermal Investigations in Ohio and Pennsylvania. Los Alamos Nat'l. Lab. Rept. LA-9223-HDR, 57 p.

5. Hendry, R., Hilfiker, K., Hodge, D., Morgan, P., Swanberg, S., and Shannon, S. S., 1982. Geothermal Investigations in West Virginia. Los Alamos Nat'l. Lab. Rept. LA-9558-HDR, $57 \mathrm{p}$.

6. D'Appolonia Consulting Engineers, Inc., 1981. Evaluation of Hot Dry Rock Exploration Techniques in the Atlantic Coastal Plain: A Test Site on the Delmarva Peninsula of Maryland and Virginia. Los Alamos Nat'l. Lab. Rept. LA-8800-MS, 28 p.

7. D'Appolonia Consulting Engineers, Inc., 1980. Hot Dry Rock Geothermal Evaluation, Cris-Wall Site, Eastern Shore of Maryland and Virginia. Unpub. Rept. Los Alamos Nat'l. Lab., 228 p.

8. Smith, D.L., and Dees, W.T., 1982. Heat Flow in the Gulf Coastal Plain. Jour. Geophys. Res. 87, pp 7687-7693.

9. Smith, D.L., and Shannon, S.S., 1982. Heat Flow Reconnaissance of the Gulf Coastal Plain. Los Alamos Nat'l Lab. Rept. LA-9222-HDR; 36 p.

10. Roy, R.F., Taylor, B., Pyron, A.J., and Maxwell, J.C., 1980. Heat Flow Measurements in the State of Arkansas. Los Alamos Nat'l. Lab. Rept. LA-8569-MS, 15 p.

11. Maxwell, J.C., LaDelfe, C.M., and Gambill, D.T., 1981. Evaluation of the Geothermal Potential of Arkansas During FY78-79. Unpub. Rept. Los Alamos Nat'l. Lab., 72 p.

12. Hinze, W., Braile, L., von Frese, R., Lidiak, E., Denison, R., Keller, G., Roy, R., Swanberg, C., Aiken, C., Morgan, P., and Gosnold, W., 1986. Exploration for Hot Dry Rock Geothermal Resources in the Midcontinent USA. Los Alamos Nat'l. Lab. Rept. LA-10659-HDR, Vol 1, $153 \mathrm{p}$.

13. Stix, J., 1982. Seasat Satellite Investigation of the Structure of Western Nebraska and its Application to the Evaluation of Geothermal Resources. Los Alamos Nat'l. Lab. Rept. LA-9275-HDR, $15 \mathrm{p}$. 


\section{APPENDIX F}

\section{Assessments of Geothermal Resources of the United States}

Muffler, L.J.P., (editor), 1979. Assessment of geothermal resources of the United States-1978, U.S. Geological Survey Circular, 790, 163 pp.

Reed, M.J., (editor), 1982. Assessment of low-temperature geothermal resources of the United States-1982, U.S. Geological Survey Circular, 892, 73 pp.

Renner, J.L., and Vaught, T.L., 1979. Geothermal Resources of the Eastern United States, Report \# DOE/NVO/1558-7, Gruy Federal, Inc, Arlington, VA, 59 pp.

White, D.E., and Williams, D.L., (editors), 1975. Assessment of Geothermal Resources of the United States-1975, U.S. Geological Survey Circular 726, 155 pp. 


\section{APPENDIX G}

\section{Authors and Contributors}

Principal Author and Editor: John H. Sass, U.S. Geological Survey.

Section II. Development and Status of HDR Technology: Gladys M. Hooper and Allan J. Jelacic, U.S. Department of Energy.

Appendix D:

Panel 1: Grant Heiken, Los Alamos National Laboratory

Panel 2: Manuel Nathenson, U.S. Geological Survey

Panel 3: Marianne C. Guffanti, U.S. Geological Survey

Panel 4: Allan J. Jelacic, U.S. Department of Energy

Appendix E: Fraser Goff and Grant Heiken, LANL.

Other Contributors: D.D. Blackwell, D.V. Duchane, John Garnish, D.W. Klick, Parker Mathusa, J.E. Mock, S.S. Priest, J.W.Tester, R.H. Wallace, Jr., Tsutomo Yamaguchi. 